\title{
Ultra-fast early Miocene exhumation of Cavalli Seamount, Northland Plateau, Southwest Pacific Ocean
}

\author{
N. MORTIMER \\ GNS Science \\ Private Bag 1930 \\ Dunedin 9054, New Zealand \\ n.mortimer@gns.cri.nz
}

\section{W. J. DUNLAP}

Research School of Earth Sciences

Australian National University

Canberra, ACT 0200, Australia

Present address Department of Geology \& Geophysics,

University of Minnesota, Minneapolis MN 55455, USA

\section{J. M. PALIN}

Department of Geology

University of Otago

PO Box 56

Dunedin 9054, New Zealand

\section{R. H. HERZER}

GNS Science

PO Box 30368

Lower Hutt 5040, New Zealand

\section{F. HAUFF}

IFM-GEOMAR Leibniz Institute for Marine Sciences

Wischhofstrasse 1-3

D-24148 Kiel, Germany

\section{CLARK}

\section{NIWA}

Private Bag 14901

Kilbirnie, Wellington 6241, New Zealand

\begin{abstract}
We present new photographic, petrological, geochronological, and isotopic data for gneissic and granitic rocks obtained from six sample stations on Cavalli Seamount during two cruises in 2002. These data lead to revision of earlier conclusions based on two dredges of schist in 1999. Based on c. $100 \mathrm{Ma}$ ages of zircon cores, and whole rock petrochemistry and tracer isotopes, we interpret the protoliths of paragneisses and orthogneisses to probably have been sedimentary and plutonic correlatives of the Late Cretaceous Houhora Complex. U-Pb dating of low $\mathrm{Th} / \mathrm{U}$ zircon rims confirms an earliest Miocene high-grade metamorphic episode. A cooling history based on Ar-Ar K-feldspar dating indicates ultra-rapid cooling (c. $2000^{\circ} \mathrm{C} / \mathrm{m}$.y.) and vertical exhumation (c. $100 \mathrm{~mm} / \mathrm{yr}$ ) of the rocks at $19.9 \mathrm{Ma}$. Our preferred tectonic model relates the amphibolite facies metamorphism to Northland Allochthon emplacement and
\end{abstract}

the rapid exhumation to dextral transtension along the Vening Meinesz Fracture Zone system and/or a rapidly retreating Pacific trench.

Keywords New Zealand; Southwest Pacific Ocean; Northland Plateau; Vening Meinesz Fracture Zone; Northland Allochthon; tectonics; exhumation; strike-slip faulting; geochronology; Miocene

\section{INTRODUCTION}

Cavalli Seamount is a prominent, flat-topped, c. $40 \times 20 \times$ $1 \mathrm{~km}$ feature located c. $100 \mathrm{~km}$ ENE of North Cape (Fig. 1, 2) (Mitchell \& Eade 1990). Geomorphically it lies off the well-defined Northland continental slope, near the edge of the Northland Plateau (Herzer et al. 2000). In a cruise in 1999, samples of schist were recovered from two dredges on the east slopes of Cavalli Seamount. Post-cruise analysis and interpretation of those rocks led Mortimer et al. (2003) to propose a Miocene metamorphic core complex model. Key results leading to this model were establishment of (1) Late Cretaceous-Paleogene sedimentary protolith and (2) rapid early Miocene exhumation.

This paper is an update of Mortimer et al. (2003) and is based on new, previously unpublished results from two cruises made in 2002 (Clark et al. 2002; Herzer et al. 2004) (Table 1). One, a dedicated geological cruise by GNS Science, made one rock dredge up the south flank of the western part of Cavalli. On a separate biological cruise by the National Institute of Water and Atmospheric Research (NIWA), rocks were recovered as "by-catch" at several stations on the seamount's flat top, and bottom camera traverses were made of the seabed. Our new samples, analyses, and images give more confidence to, and supplement, the interpretations made by Mortimer et al. (2003).

With the publication of dredging results from the Northland Plateau (Mortimer et al. 2007), it is now possible to view Cavalli in an onland-offshore geological context (Fig. 1). Much of the Northland continental shelf edge $(<1500 \mathrm{~m}$ water depth) is underlain by the Vening Meinesz Fracture Zone (VMFZ) system of faults. Cavalli Seamount and the Northland Plateau (a broad region of mainly Miocene volcanoes) lie between the VMFZ and the edge of the Kupe Abyssal Plain of the South Fiji Basin (c. $3000 \mathrm{~m}$ water depth). Cavalli Seamount separates the Knights and Whangaroa Basins. The autochthonous basement geology of onland Northland comprises Waipapa Terrane (Permian-Jurassic greywackeargillite association with minor basalt-chert-limestone) and Houhora Complex (Late Cretaceous intercalated submarine basalt, andesite, dacite, rhyolite, tuff-breccia, conglomerate, sandstone, and mudstone) (Isaac et al. 1994; Isaac 1996). Houhora Complex igneous rocks have given $\mathrm{U}-\mathrm{Pb}$ zircon ages of c. $102 \mathrm{Ma}$ (GNS unpubl. data). Late Cretaceous-Oligocene sedimentary rocks rest unconformably on the basement. 


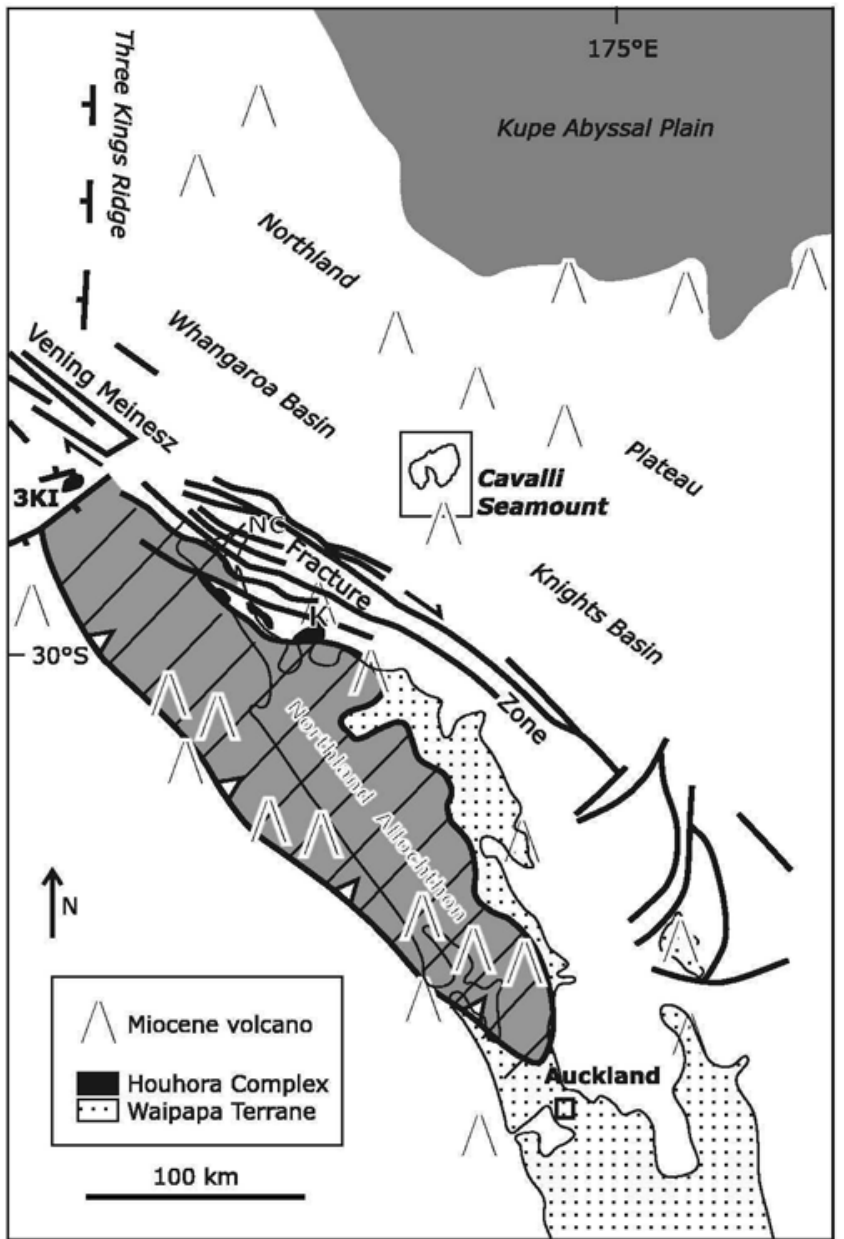

Fig. 1 Location of Cavalli Seamount ( $1200 \mathrm{~m}$ isobath shown) in relation to neighbouring geological features of onland and offshore Northland. Only onshore and western parts of the allochthon are shown. Late Cretaceous-Pleistocene sedimentary cover are not shown. $3 \mathrm{KI}=$ Three Kings Islands, NC = North Cape, $\mathrm{K}=$ Karikari Peninsula. Rectangle is area of Fig. 2. After Isaac et al. (1994), Herzer \& Mascle (1996), and Mortimer et al. (2007).

Tectonically overlying the autochthonous rocks is a nowsouthwest-tilted thrust sheet, the Northland Allochthon, which was emplaced in the Waitakian (early Miocene, 25-22 Ma). Following allochthon emplacement, early Miocene volcanoes of the Northland Arc erupted through and onto the allochthon and, probably in the same early-middle Miocene time interval, the dextral VMFZ juxtaposed rocks of the Northland Plateau, including Cavalli Seamount, against the Northland continental margin (Fig. 1).

\section{METHODS}

With a few exceptions, $\mathrm{X}$-ray fluorescence (XRF), inductively coupled plasma mass spectrometry (ICP-MS), Ar-Ar and U-Pb dating, and $\mathrm{Sr}, \mathrm{Nd}$ and $\mathrm{Pb}$ isotopic analytical methods are identical to those reported in Mortimer et al. (2006, appendix DR1). After analysing the whole rocks by ICP-MS with acid dissolution, it was realised that there were unrealistically low concentrations of $\mathrm{Zr}$ and rare-earth elements, presumably due to incomplete sample dissolution of minerals such as zircon.

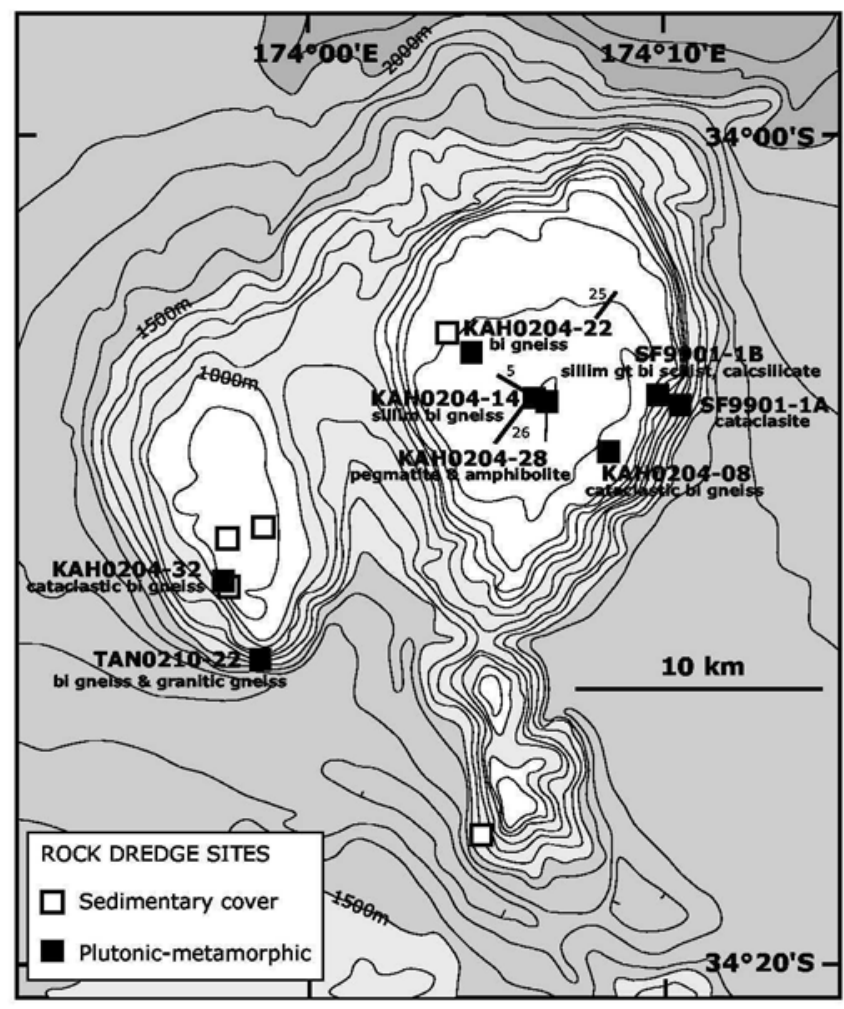

Fig. 2 Location of dredge sites, and plutonic-metamorphic rock types obtained from Cavalli Seamount on GNS Tangaroa cruises SF9901 and TAN0210, and on NIWA Kaharoa cruise KAH0204. Kaharoa camera station tracks 5 and 25 also shown. Bathymetry from Mitchell \& Eade (1990). For sample details see Table 1.

Samples were thus reanalysed by ICP-MS using fused bead dissolution, as indicated in Table 2. The analytical approach used in ${ }^{40} \mathrm{Ar}{ }^{39} \mathrm{Ar}$ analysis is identical to that outlined in Dunlap (2003), except for the following: correction factors used are $\left({ }^{37} \mathrm{Ar}{ }^{\beta 9} \mathrm{Ar}\right)_{\mathrm{Ca}}=3.50 \times 10^{-4},\left({ }^{39} \mathrm{Ar}{ }^{\beta 7} \mathrm{Ar}\right)_{\mathrm{Ca}}=7.86 \times$ $10^{-4},\left({ }^{40} \mathrm{Ar} /{ }^{39} \mathrm{Ar}\right)_{\mathrm{K}}=0.027$. The individual step ages of the K-feldspar were calculated using the Fish Canyon sanidine neutron fluence (dose) monitor, which has an intercalibrated age of $28.1 \pm 0.04 \mathrm{Ma}$ (Spell \& McDougall 2003).

All samples have been lodged in the GNS Petrology "P" Collection, and associated sample and analytical data have been catalogued in the PETLAB database (http://pet.gns.cri. $\mathrm{nz})$.

\section{SAMPLE DATA}

During the KAH0204 cruise, 317 photographs were taken during the course of 11 still-camera tows across the tops of the eastern and western parts of Cavalli Seamount. In most cases the camera faced vertically down, perpendicular to the seafloor. The camera was not deliberately oriented, the purpose being to take biological images. We believe that the long axis of the photographs was probably oriented parallel to the ship's track, although the possibility of cross-currents and local sled disturbances means we cannot be entirely sure of this. In situ rock exposures (as opposed to sandy or muddy bottom) were visible in about one-fifth of the photographs, and 21 photographs in nine different tows showed a significant 
Table 1 Sample location and description data for Cavalli samples dredged in 1999 and 2002.

\begin{tabular}{|c|c|c|c|c|}
\hline GNS P\# & Deck\# & Sample size & Rock names & Notes \\
\hline $\begin{array}{l}\text { SF9901-1 } \\
63144-48\end{array}$ & $\begin{array}{l}\text { Mar } 99,-34.10 \\
\text { D1A }-1-4\end{array}$ & $\begin{array}{l}\text { 174.1781E, 985-1229 m } \\
<1 \mathrm{~kg}\end{array}$ & cataclastic schist & See Mortimer et al. (2003). \\
\hline $\begin{array}{l}\text { SF9901-1 } \\
62586,62\end{array}$ & $\begin{array}{l}\mathbf{M a r} 99,-34.10 \\
65,63139-6314\end{array}$ & $\begin{array}{l}\text { 174.1668E, 577-778 m } \\
00 \mathrm{~kg}\end{array}$ & gt bi schist and calcsilicate gneiss & See Mortimer et al. (2003). \\
\hline $\begin{array}{l}\text { KAH020 } \\
67667\end{array}$ & $\begin{array}{l}\text { 14 Apr 02, }-34 \text {. } \\
\text { D8-1 }\end{array}$ & $\begin{array}{l}5,174.1450 \mathrm{E}, 610-640 \mathrm{~m} \\
30 \times 20 \times 20 \mathrm{~cm} \text { angular with broken face }\end{array}$ & cataclastic biotite schist/gneiss & $\begin{array}{l}\text { Cataclastic textures prominent. Biotite retrograded to chlorite. } \\
\text { Faults grade into open cracks with calcooze infilling. }\end{array}$ \\
\hline $\begin{array}{l}\text { KAH020 } \\
67670\end{array}$ & $\begin{array}{l}15 \text { Apr 02, }-34 \text {. } \\
\text { D14-1 }\end{array}$ & $\begin{array}{l}\text { S, 174.1105E, 507-520 m } \\
35 \times 25 \times 10 \mathrm{~cm} \text { slab }\end{array}$ & $\begin{array}{l}\text { biotite paragneiss and } \\
\text { orthogneiss }\end{array}$ & Fine-grained biotite gneiss in contact with coarser perthitic biotite gneiss. \\
\hline 67671 & D14-2 & $20 \times 15 \times 10 \mathrm{~cm}$ angular, irregular & sillimanite biotite paragneiss & Quartz, oligoclase, biotite, garnet, sillimanite, FeTi oxide, titanite, muscovite. \\
\hline $\begin{array}{l}\text { КАН020 } \\
67673^{*} \\
67674\end{array}$ & $\begin{array}{l}16 \text { Apr 02, }-34 . \\
\text { D22-1 } \\
\text { D22-2 }\end{array}$ & $\begin{array}{l}174.0787 \mathrm{E}, 550-610 \mathrm{~m} \\
15 \times 10 \times 7 \mathrm{~cm} \text {, angular with broken face } \\
20 \times 20 \times 7 \mathrm{~cm} \text { angular }\end{array}$ & $\begin{array}{l}\text { granodioritic orthogneiss } \\
\text { granodioritic orthogneiss }\end{array}$ & $\begin{array}{l}\text { Weakly foliated. Granodioritic composition from geochemistry. } \\
\text { Weakly foliated. Identical to P } 67670 \text {. }\end{array}$ \\
\hline $\begin{array}{l}\text { КАН020 } \\
67676\end{array}$ & $\begin{array}{l}\text { 16 Apr 02, -34. } \\
\text { D28-1 }\end{array}$ & $\begin{array}{l}\mathbf{S}, \mathbf{1 7 4 . 1 1 4 8 E}, \mathbf{4 9 0}-515 \mathrm{~m} \\
10 \times 7 \times 4 \mathrm{~cm} \text { subangular block }\end{array}$ & pegmatite and amphibolite & $\begin{array}{l}\text { Garnet hornblendite (inclusion?) in contact with (larger mass of?) granite } \\
\text { pegmatite, median grain size } 8 \mathrm{~mm} \text {. }\end{array}$ \\
\hline $\begin{array}{l}\text { KAH020 } \\
67678^{*}\end{array}$ & $\begin{array}{l}17 \text { Apr 02, }-34 \text {. } \\
\text { D32-1 }\end{array}$ & $\begin{array}{l}\text {, 173.9618E, } 780-810 \mathrm{~m} \\
4 \times 3 \times 2 \mathrm{~cm} \text { angular }\end{array}$ & cataclastic biotite paragneiss & Grey-green hard rebrecciated and sediment-cemented cataclastic gneiss. \\
\hline $\begin{array}{l}\text { TAN0210 } \\
66836\end{array}$ & $\begin{array}{l}5 \text { Aug 02, }-34.20 \\
\text { D22-1A }\end{array}$ & $\begin{array}{l}\text { 173.9784E, } 1330-1750 \mathrm{~m} \\
5-50 \mathrm{~cm} \text { subangular boulder }\end{array}$ & banded biotite paragneiss & $\begin{array}{l}20 \% \text { quartz, } 60 \% \text { oligoclase, } 15 \% \text { biotite, } 5 \% \text { anhedral garnet, FeTi oxide, } \\
\text { titanite, graphite, apatite } 0.3 \mathrm{~mm} \text { median grain size. Cut by } 1 \mathrm{~cm} \text { irregular } \\
\text { veins of granitic gneiss (see P } 66839 \text { ) that are subparallel to, and crosscut but } \\
\text { predate, the main foliation. }\end{array}$ \\
\hline 66837 & D22-1B & $5-50 \mathrm{~cm}$ subangular boulder & banded biotite paragneiss & $\begin{array}{l}\text { Similar to P66836 but with mica segregations spaced at } 5 \mathrm{~mm} \text {. Biotite is } \\
\text { more oxidised. Granitic veins are more intimately interbanded and the whole } \\
\text { rock analysis is probbaly a mix of host gneiss and granite. }\end{array}$ \\
\hline $\begin{array}{l}66838 \\
66839\end{array}$ & $\begin{array}{l}\text { D22-1C } \\
\text { D22-2A }\end{array}$ & $\begin{array}{l}5-50 \mathrm{~cm} \text { subangular boulder } \\
40 \times 30 \times 20 \mathrm{~cm} \text { angular slab }\end{array}$ & $\begin{array}{l}\text { migmatitic gneiss } \\
\text { granitic orthogneiss }\end{array}$ & $\begin{array}{l}\text { Up to half of sample is irregular granitic veins. Forams in crack infill. } \\
50 \% \text { quartz, } 20 \% \mathrm{~K} \text {-feldspar, } 25 \% \text { plagioclase, } 5 \% \text { chloritised biotite, FeTi } \\
\text { oxides, secondary muscovite. Weakly foliated. }\end{array}$ \\
\hline 66840 & D22-2B & $5-50 \mathrm{~cm}$ subangular boulder & folded, veined biotite gneiss & $\begin{array}{l}\text { Similar to P66838. Irregular (pytgmatic, pre-main foliation) granitic veins up to } \\
2 \mathrm{~cm} \text { wide cut gneiss. Accessory tourmaline in one granitic vein. }\end{array}$ \\
\hline 66841 & D22-3 & $5-20 \mathrm{~cm}$ bored subrounded slab & soft sandy mudstone & Bioturbated, foram-bearing, some gneissic clasts. \\
\hline 66842 & D22-4 & $5-20 \mathrm{~cm}$ bored subrounded slab & hard brown sandstone & Some gneissic clasts. \\
\hline
\end{tabular}

*No thin section: hand sample description only. 
Table 2 Whole rock analyses of Cavalli samples dredged in 2002.

\begin{tabular}{|c|c|c|c|c|c|}
\hline $\begin{array}{l}\text { GNS P\# } \\
\text { Dredge } \\
\text { rock }\end{array}$ & $\begin{array}{c}\text { P66836 } \\
\text { SF0202-22 } \\
\text { biotite paragneiss } \\
\end{array}$ & $\begin{array}{c}\text { P66837 } \\
\text { SF0202-22 } \\
\text { biotite and granite gneiss } \\
\end{array}$ & $\begin{array}{c}\text { P66839 } \\
\text { SF0202-22 } \\
\text { granitic orthogneiss }\end{array}$ & $\begin{array}{c}\text { P67673 } \\
\text { KAH0204-22 } \\
\text { granodioritic orthogneiss }\end{array}$ & $\begin{array}{c}\text { P67674 } \\
\text { KAH0204-22 } \\
\text { granodioritic orthogneiss }\end{array}$ \\
\hline $\mathrm{SiO}_{2}(\mathrm{wt} \%)$ & 66.27 & 71.22 & 73.79 & 64.01 & 62.69 \\
\hline $\mathrm{TiO}_{2}$ & 0.67 & 0.64 & 0.10 & 0.56 & 0.61 \\
\hline $\mathrm{Al}_{2} \mathrm{O}_{3}$ & 17.19 & 14.22 & 14.84 & 15.20 & 15.38 \\
\hline $\mathrm{Fe}_{2} \mathrm{O}_{3} \mathrm{~T}$ & 3.51 & 4.88 & 0.70 & 4.04 & 4.42 \\
\hline $\mathrm{MnO}$ & 0.07 & 0.06 & 0.01 & 0.07 & 0.07 \\
\hline $\mathrm{MgO}$ & 1.22 & 1.42 & 0.27 & 1.90 & 1.88 \\
\hline $\mathrm{CaO}$ & 2.87 & 0.74 & 1.41 & 4.20 & 4.56 \\
\hline $\mathrm{Na}_{2} \mathrm{O}$ & 4.39 & 2.01 & 4.18 & 4.33 & 4.39 \\
\hline $\mathrm{K}_{2} \mathrm{O}$ & 2.64 & 2.83 & 3.94 & 2.68 & 3.01 \\
\hline $\mathrm{P}_{2} \mathrm{O}_{5}$ & 0.10 & 0.07 & 0.10 & 0.19 & 0.19 \\
\hline LOI & 0.84 & 1.82 & 0.52 & 2.53 & 2.74 \\
\hline Total & 99.77 & 99.90 & 99.86 & 99.69 & 99.94 \\
\hline As (ppm) & $<1$ & 3 & 1 & $<1$ & $<1$ \\
\hline $\mathrm{Ba}$ & 1010 & 599 & 708 & 704 & 810 \\
\hline $\mathrm{Ce}$ & 78.7 & 56.2 & 31.1 & 56.3 & 63.1 \\
\hline Co & na & 50.5 & 76.9 & 71.4 & 59.3 \\
\hline $\mathrm{Cr}$ & 21 & 44 & $<1$ & 26 & 26 \\
\hline Cs & 2.50 & 3.08 & 2.53 & 3.60 & 3.60 \\
\hline $\mathrm{Cu}$ & 18 & 22 & 2 & 2 & 7 \\
\hline Dy & 6.89 & 3.37 & 2.46 & 3.34 & 3.74 \\
\hline $\mathrm{Er}$ & 4.03 & 1.98 & 1.32 & 1.86 & 2.09 \\
\hline $\mathrm{Eu}$ & 1.47 & 0.688 & 0.227 & 0.907 & 0.953 \\
\hline $\mathrm{Ga}$ & 22.7 & 18.98 & 17.9 & 19.6 & 20.8 \\
\hline Gd & 7.17 & 3.89 & 2.69 & 4.07 & 4.39 \\
\hline $\mathrm{Hf}$ & 7.91 & 7.52 & 2.58 & 5.09 & 7.11 \\
\hline Ho & 1.39 & 0.709 & 0.473 & 0.649 & 0.732 \\
\hline $\mathrm{La}$ & 34 & 24.4 & 15.4 & 27.4 & 30.8 \\
\hline $\mathrm{Li}$ & na & 24.5 & 4.54 & 22.1 & 25.2 \\
\hline $\mathrm{Lu}$ & 0.643 & 0.360 & 0.202 & 0.305 & 0.341 \\
\hline Mo & na & 0.601 & 0.127 & 0.193 & 0.129 \\
\hline $\mathrm{Nb}$ & 13.0 & 9.48 & 7.09 & 5.97 & 8.68 \\
\hline $\mathrm{Nd}$ & 37.1 & 23.4 & 12.2 & 24.8 & 27.9 \\
\hline $\mathrm{Ni}$ & 13 & 26 & $<2$ & 19 & 15 \\
\hline $\mathrm{Pb}$ & 30.1 & 15.6 & 26.8 & 17.9 & 16.9 \\
\hline $\operatorname{Pr}$ & 9.55 & 6.32 & 3.46 & 6.76 & 7.53 \\
\hline $\mathrm{Rb}$ & 93.9 & 102 & 128 & 89.3 & 95.6 \\
\hline $\mathrm{Sb}$ & na & 0.184 & 0.093 & 0.043 & 0.054 \\
\hline $\mathrm{Sc}$ & 11 & 12 & $<2$ & 12 & 12 \\
\hline $\mathrm{Sm}$ & 7.74 & 4.52 & 2.67 & 4.73 & 5.23 \\
\hline Sn & na & 0.940 & 2.03 & 2.14 & 2.23 \\
\hline $\mathrm{Sr}$ & 511 & 161 & 190 & 534 & 530 \\
\hline $\mathrm{Ta}$ & na & 0.191 & 0.795 & 0.475 & 0.375 \\
\hline $\mathrm{Tb}$ & 1.17 & 0.543 & 0.396 & 0.591 & 0.653 \\
\hline Th & 11.9 & 10.6 & 7.77 & 9.47 & 10.7 \\
\hline $\mathrm{T} 1$ & na & 0.731 & 0.632 & 0.581 & 0.653 \\
\hline $\mathrm{Tm}$ & 0.609 & 0.309 & 0.199 & 0.280 & 0.317 \\
\hline U & 3.22 & 2.31 & 2.90 & 1.71 & 2.07 \\
\hline V & 57.8 & 83.3 & 8.46 & 69.9 & 76.7 \\
\hline $\mathrm{Y}$ & 39.2 & 18.5 & 15.3 & 18.6 & 20.5 \\
\hline $\mathrm{Yb}$ & 4.21 & 2.24 & 1.40 & 2.02 & 2.23 \\
\hline Zn & 80.8 & 89.1 & 15.0 & 64.7 & 64.6 \\
\hline $\mathrm{Zr}$ & 267 & 254 & 65 & 175 & 199 \\
\hline \multirow[t]{2}{*}{${ }^{87} \mathrm{Sr} r^{86} \mathrm{Sr} \pm 2 \sigma$} & 0.708922 & 0.709483 & 0.706886 & 0.705913 & 0.705919 \\
\hline & 0.000004 & 0.000004 & 0.000004 & 0.000004 & 0.000005 \\
\hline \multirow[t]{2}{*}{${ }^{143} \mathrm{Nd} /{ }^{144} \mathrm{Nd} \pm 2 \sigma$} & 0.512659 & 0.512471 & 0.512643 & 0.512553 & 0.512553 \\
\hline & 0.000002 & 0.000002 & 0.000002 & 0.000002 & 0.000002 \\
\hline \multirow[t]{2}{*}{${ }^{206} \mathrm{~Pb} /{ }^{204} \mathrm{~Pb} \pm 2 \sigma$} & 18.833 & 18.839 & 18.833 & 18.841 & 18.838 \\
\hline & 0.001 & 0.001 & 0.001 & 0.001 & 0.001 \\
\hline \multirow[t]{2}{*}{${ }^{207} \mathrm{~Pb} /{ }^{204} \mathrm{~Pb} \pm 2 \sigma$} & 15.628 & 15.629 & 15.619 & 15.621 & 15.615 \\
\hline & 0.001 & 0.001 & 0.001 & 0.001 & 0.001 \\
\hline \multirow[t]{2}{*}{${ }^{208} \mathrm{~Pb} /{ }^{204} \mathrm{~Pb} \pm 2 \sigma$} & 38.736 & 38.758 & 38.707 & 38.798 & 38.780 \\
\hline & 0.001 & 0.002 & 0.001 & 0.001 & 0.001 \\
\hline
\end{tabular}

Major elements and As, $\mathrm{Cr}, \mathrm{Cu}, \mathrm{Ni}, \mathrm{Sc}$, and $\mathrm{Zr}$ by X-ray fluorescence methods at Spectrachem Analytical. Li, Co, Mo, Sb, Sn, Ta and Tl by ICP-MS dissolution methods at University of Kiel. All other elements by ICP-MS fused bead methods at University of Kiel. LOI = Loss on ignition, $\mathrm{na}=$ not analysed. 

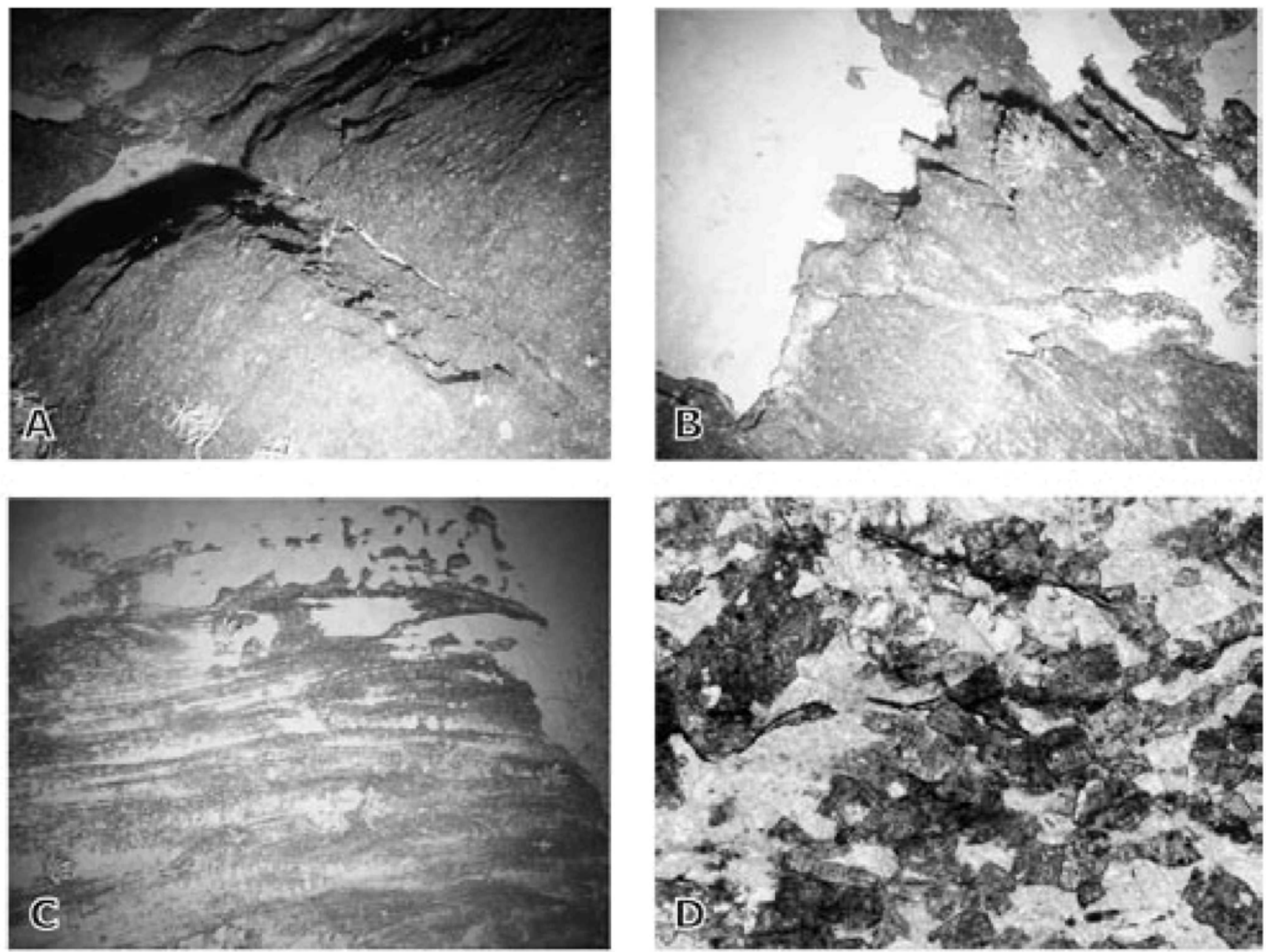

Fig. 3 KAH0204 camera images of Cavalli seafloor; field of view c. 2 m (see Fig. 2 for locations), inferred azimuths are speculative (see text for discussion). A, Station 5, photo 8928, showing moderately developed subhorizontal gneiss foliation cut by sediment-filled subvertical joint which possibly strikes 170 . B, Station 25 , photo 9351 , showing well-developed subhorizontal gneiss foliation with a pronounced penetrative lineation that has a possible azimuth of 075 . C, Station 26 , photo 9369 , showing rare subvertically dipping foliation with possible strike of 040 . D, Microscope image of dated granitic orthogneiss P66839, $5 \mathrm{~mm}$ wide, taken in plane polarised light.

measure of photogeological detail. In most of these, the shadows cast by rock mass edges revealed the presence of a subhorizontally dipping planar anisotropic fabric, inferred to be metamorphic foliation (e.g,. Fig. 3A,B). In one case, steeply dipping, possibly isoclinally folded foliation appeared to be exposed on a subhorizontal joint face (Fig. 3C).

A summary of the hand specimen and petrographic characteristics of the igneous and metamorphic samples is given in Table 1. Including the two 1999 dredge sites, metamorphic and plutonic rocks have now been obtained from eight sample sites up to $20 \mathrm{~km}$ apart on the eastern and western parts of Cavalli Seamount (Fig. 2). In contrast to neighbouring seamounts on the Northland Plateau and continental shelf, which are extinct volcanoes (Fig. 1), it is significant that no volcanic or volcaniclastic rocks have thus far been obtained from Cavalli Seamount. This suggests that the entire seamount represents a significant submarine outcrop of continental metamorphic rocks.

Compared with the rocks dredged in 1999, no calcsilicate gneiss was sampled. The textures of the 2002 biotite-bearing metamorphic rocks are more semischistose-granoblastic than schistose, and have relatively poor fissility compared to the 1999 rocks. Hence, in the absence of mesoscopic field criteria, we describe the 2002 rocks as gneisses rather than schists (Compton 1985) but acknowledge there is probably a gradation between these rock types. The metamorphic mineral assemblages in the 2002 biotite gneisses are the same as in the 1999 biotite schists, with the index mineral sillimanite being present in gneiss P67671 from the eastern seamount top. Layering and heterogeneity probably indicates that most of the biotite gneisses had a metasedimentary protolith, and we refer to them as paragneisses.

Plutonic rocks were entirely absent from the two 1999 dredges. However, in the 2002 dredges, significant occurrences of metaplutonic rocks (granitic and dioritic gneiss) were discovered on both the eastern and western parts of the seamount (Fig. 2). These rock types occur both as deformed granitic veins in gneiss (e.g., P67670, P66838) and as separate boulders of granitic and dioritic gneiss (e.g., P66839). Foliation in the metaplutonic rocks is much weaker than in the aforementioned biotite gneisses, and banding is absent (Fig. 2). A sample of pegmatite vein cutting amphibolite (P67676) was obtained from the eastern top of the seamount. 

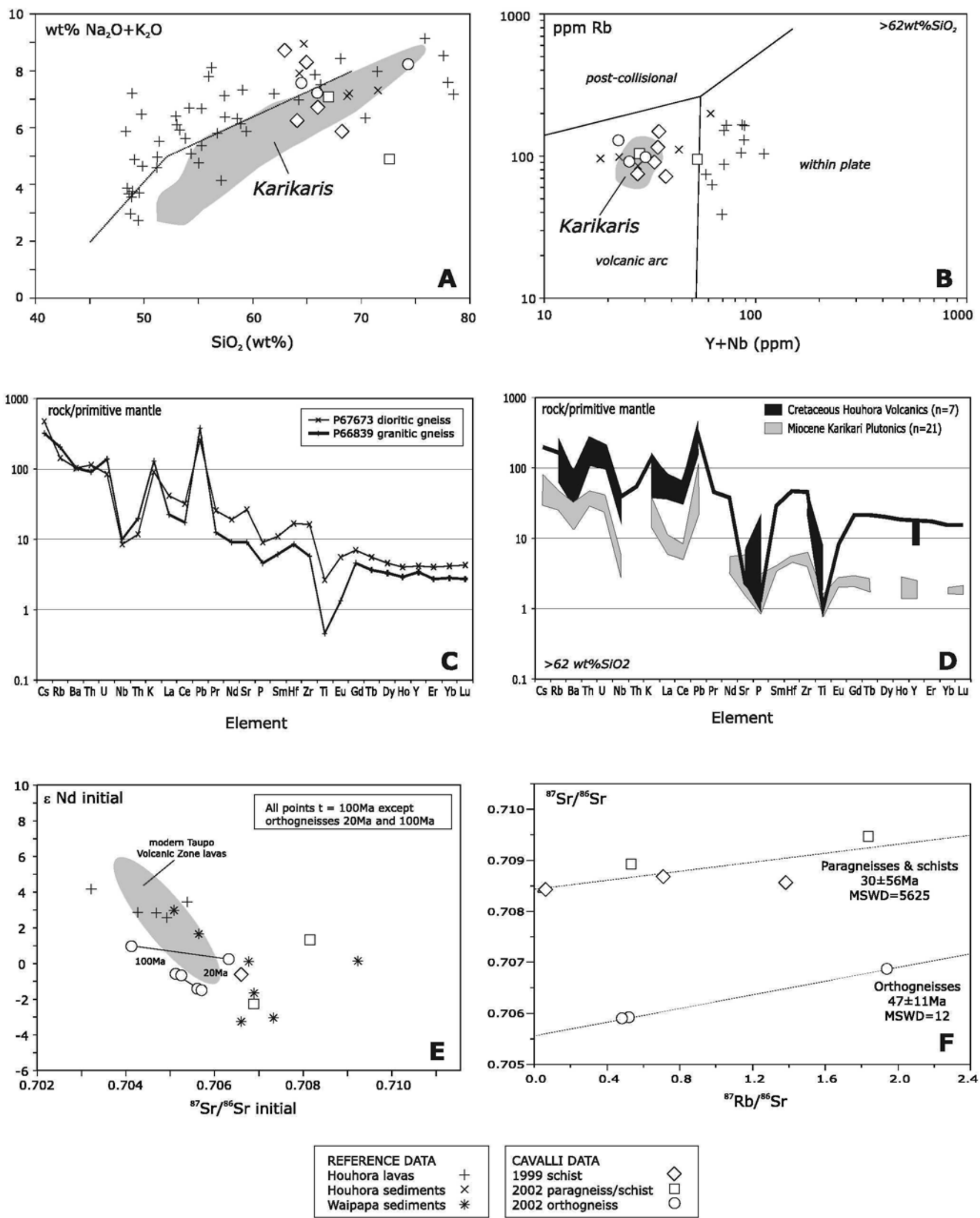

Fig. 4 Whole rock chemistry isotopic composition of Cavalli Seamount rocks compared with possible correlatives. A, Silica versus total alkalies diagram. B, Siliceous igneous rocks trace element diagram (Whalen et al. 1987). C, D, Primitive mantle normalised multi-element diagram (Sun \& McDonough 1989). E, Sr versus Nd tracer isotope diagram. F, Strontium isochron diagram (no useful age information can be derived from the isochron lines, they are plotted for reference only). Reference data from Ruddock (1990), McCulloch et al. (1994), Palmer et al. (1995), Nicholson et al. (2000), Nicholson \& Black (2004), Adams et al. (2005), and Mortimer et al. (1998, 2003, 2006). 


\section{ANALYTICAL DATA}

\section{Petrochemistry}

\section{Paragneisses}

Mortimer et al. (2003) discussed the usefulness and limitations of petrography and of whole rock geochemical and isotopic analyses in helping correlate the metasedimentary rocks with specific geological units. Basically, the banded biotite gneisses in this study have broadly similar compositions to the 1999 biotite schists, but overall are slightly more silicarich. Whole rock and tracer isotope data are compatible with any one of a number of local sources from Waipapa Terrane and Houhora Complex basement, to cover sequences eroded therefrom (Fig. 4). Dating of detrital zircons (see below) is more informative for stratigraphic correlation.

\section{Orthogneisses}

Three analyses of the weakly foliated metaplutonic rocks were made. The two samples from KAH0204-22 are similar in composition to each other and are essentially duplicate samples. They are granodiorites according to the petrochemical scheme of Middlemost (1994). The third sample, P66839, is granitic (Table 1, 2; Fig. 2B) and has $1.3 \mathrm{wt} \%$ corundum in the norm (i.e., it is peraluminous).

A silica versus total alkalies diagram (Fig. 4A) has limitations for metamorphic rocks. However, in overall bulk composition, the granodioritic orthogneisses are somewhat similar to the paragneisses (Fig. 4A,B) but the two sets of gneisses plot on different arrays on an $\mathrm{Rb}$-Sr isochron diagram, the paragneisses being more radiogenic (Fig. 4F). In terms of whole rock geochemistry, possible Northland correlatives of the orthogneisses are the Cretaceous (c. $100 \mathrm{Ma}$ ) Houhora Complex (Isaac et al. 1994; Isaac 1996; Nicholson \& Black 2004) and the early Miocene (c. $20 \mathrm{Ma}$ ) Karikari plutonics (Ruddock 1990; Isaac 1996) which are part of the early Miocene Northland Arc. Alternatively, they could be a new suite of igneous rocks that have no onland equivalent. On a silica versus total alkalies diagram (Fig. 4A), both Houhora and Karikari suites are plausible correlatives for the Cavalli orthogneisses. In terms of trace element contents in the same silica range, the Cavalli orthogneisses have the distinctive high large ion lithophile element content (LILE, e.g., Cs, $\mathrm{Rb}, \mathrm{Ba}, \mathrm{Th}, \mathrm{U}, \mathrm{K}$ ) of the Houhora Complex. Concentrations of high field strength (HFS, e.g., Y, Nb, Zr) and rare-earth elements (REE) are slightly lower and fall between the range of known Houhora Complex and those reported for the Karikari Plutonics. Part of this poor match may result from the fact that there exists a paucity of published trace element data on the Houhora and Northland Arc rocks, and the Cavalli samples number only three. $\mathrm{Sr}$ and $\mathrm{Nd}$ isotopic data are likewise not distinctive (Fig. 4E), but if the Houhora Complex reference set contained dacites and rhyolites (like that shown for Taupo Volcanic Zone), then a better match might be obtained.

\section{U-Pb dating}

Zircon grains were separated from two samples, P66836 biotite paragneiss and P66839 granitic orthogneiss, using standard mineral separation techniques. Before dating, cathodoluminescence images of grains were used to identify target spots on cores and rims where possible. A total of 36 dates were obtained from 29 spot analyses for P66836 and 39 dates from 39 spots for P66839 (Tables 3, 4).
Both samples gave broadly similar results: most of the data fall into two distinct age populations, 20-23 $\mathrm{Ma}$ and 98-99 $\mathrm{Ma}$, with scattered intermediate ages and several inherited grains (Fig. 5). For orthogneiss P66839, the principal age populations are $19.7 \pm 0.8 \mathrm{Ma}(2 \sigma$ error, $n=5, \mathrm{MSWD}=$ $2.05)$ and $98.3 \pm 1.6 \mathrm{Ma}(2 \sigma$ error, $n=13, \mathrm{MSWD}=1.16)$. For paragneiss $\mathrm{P} 66836$, the principal age populations are $22.9 \pm 0.6 \mathrm{Ma}(2 \sigma$ error, $n=7, \mathrm{MSWD}=1.72)$ and $99.2 \pm$ $1.4 \mathrm{Ma}(2 \sigma$ error, $n=14$, MSWD $=1.31)$. A large number of grains in the orthogneiss P66839 gave a range of ages intermediate between the two principal age populations. With the relatively low precision of the LA-ICP-MS method, some of these intermediate ages appear concordant (Fig. 5), but ${ }^{208} \mathrm{~Pb} /{ }^{232} \mathrm{Th}$ data indicate they are not. A total of six grains in the paragneiss and one grain in the orthogneiss had ${ }^{206} \mathrm{~Pb} /{ }^{238} \mathrm{U}$ ages of 120-610 Ma, which we interpret as inherited detrital cores. The ages of these inherited grains broadly match those of detrital zircons from the Waipapa Terrane basement of onland Northland (Adams et al. 2007). All spots that yielded early Miocene ages (resolved rims in the case of grains from P66836) have high U concentrations and correspondingly low $\mathrm{Th} / \mathrm{U}$ ratios compatible with a metamorphic origin (Rubatto 2002; Hoskin \& Schaltegger 2003). In contrast, spots with Late Cretaceous ages have $\mathrm{U}$ concentrations and $\mathrm{Th} / \mathrm{U}$ ratios more consistent with an igneous paragenesis.

\section{Ar-Ar and K-Ar dating}

$\mathrm{K}$-feldspar is plentiful in the weakly foliated granitic orthogneiss P66839 (Fig. 3D). A step heating experiment reveals an essentially flat plateau from which a very precise age of $19.89 \pm 0.05 \mathrm{Ma}(2 \sigma)$ can be obtained (Fig. 6, Table $5)$. There is no statistically significant slope on this plateau. Thermal modelling of the spectrum to obtain a $350-150^{\circ} \mathrm{C}$ time versus temperature cooling curve was not done, as the result would simply be a line parallel to the temperature axis at $19.9 \mathrm{Ma}$. It is clear that P66839 has cooled exceptionally rapidly for a holocrystalline high grade metaplutonic rock with a 1-2 mm grain size. Taking the error limits literally, this would amount to some $200^{\circ} \mathrm{C}$ in $100000 \mathrm{yr}$ for this part of West Cavalli Seamount, a result more than three times the maximum cooling rate inferred for part of East Cavalli by Mortimer et al. (2003). Assuming a geobarometric depth of c. $10 \mathrm{~km}$ for the rocks (Mortimer et al. 2003), this converts to a vertical exhumation rate of $100 \mathrm{~mm} / \mathrm{yr}$. The Cavalli rocks are thus at the extreme upper limit of known cooling and exhumation rates from a wide range of geological settings (Ring et al. 1999; Dunlap 2000; Rubatto \& Herrmann 2001).

Biotite from granodioritic orthogneiss $\mathrm{P} 67674$ gave a $\mathrm{K}-\mathrm{Ar}$ age of $19.3 \pm 0.5 \mathrm{Ma}\left(\mathrm{K}=6.72 \mathrm{wt} \%,{ }^{40} \mathrm{Ar}^{*}=2.22 \times\right.$ $\left.10^{-10} \mathrm{~mol} / \mathrm{g}, \%^{40} \mathrm{Ar}^{*}=46.5\right)$.

\section{DISCUSSION}

\section{Protoliths}

\section{Paragneiss}

The dominance of zircon grains of c. $100 \mathrm{Ma}$ age with igneous parentage in the paragneiss suggests a strong detrital influence from rocks similar in age to the c. $100 \mathrm{Ma}$ Houhora Complex (Isaac et al. 1994; Isaac 1996). We cannot, on existing data, firmly establish if the protoliths were actually Cretaceous 

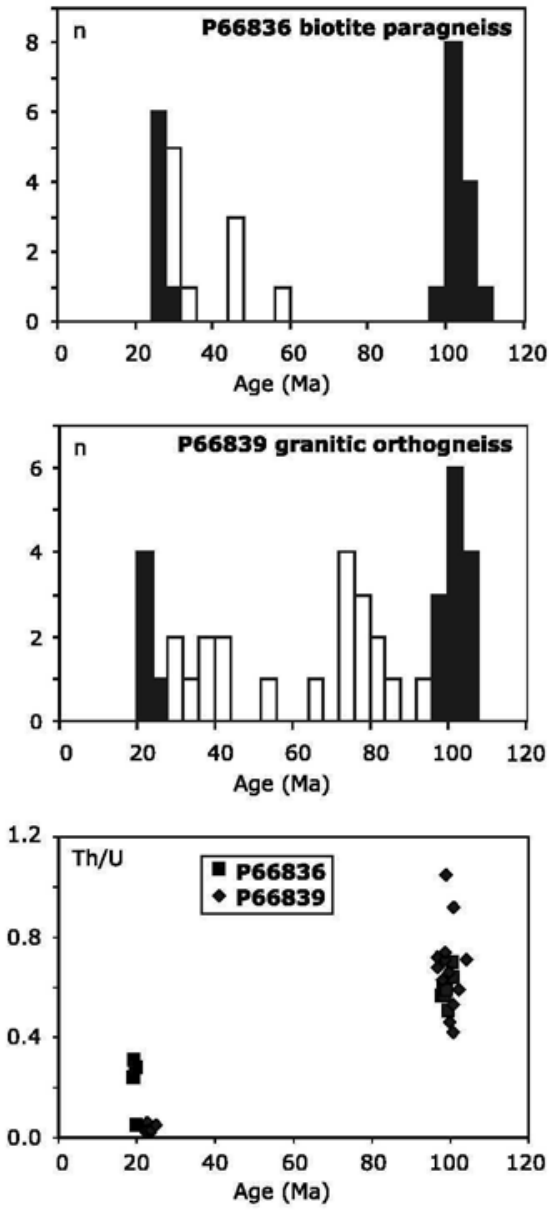
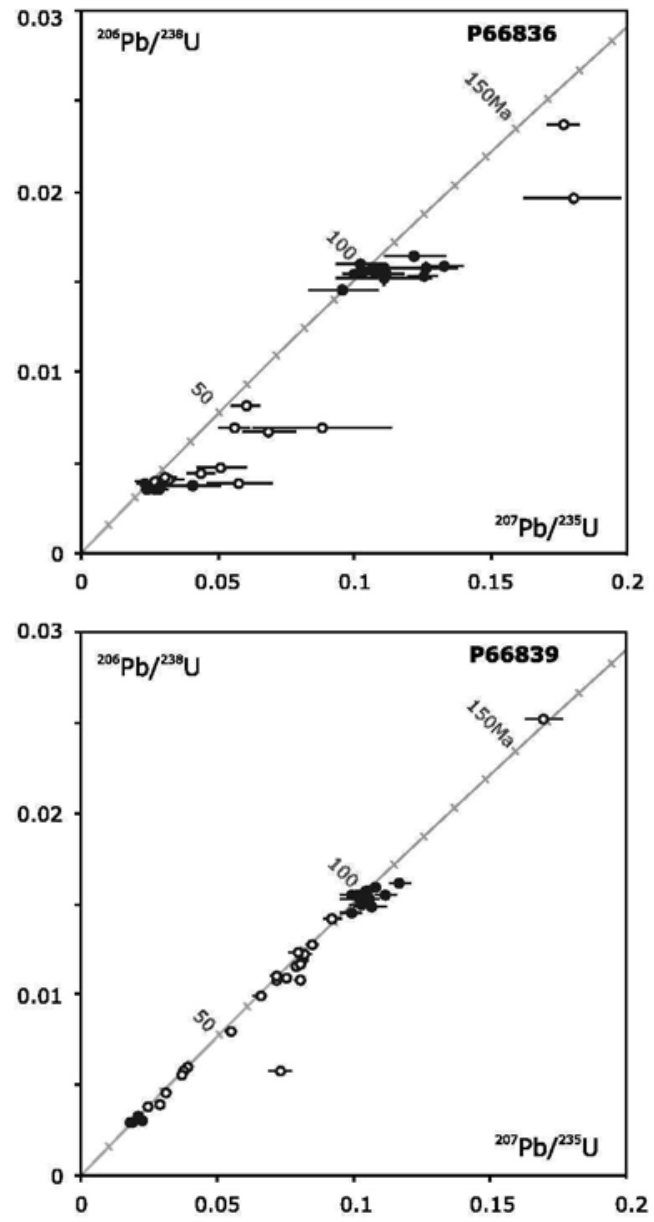

Fig. $5 \mathrm{U}-\mathrm{Pb}$ ages and $\mathrm{Th} / \mathrm{U}$ ratios of zircon grains from garnet biotite paragneiss $\mathrm{P} 66836$ and granitic orthogneiss P66839. Black symbols are concordant analyses that gave pooled early Miocene and Late Cretaceous age populations. White symbols are discordant analyses excluded from the early Miocene and Late Cretaceous age populations. strata or, like the schist dated by Mortimer et al. (2003), probable Cenozoic strata whose detrital mineralogy was derived from local basement (in this case mainly Houhora Complex with minor Waipapa Terrane). If a Cretaceous age for the intruding orthogneisses is accepted (see below) then the West Cavalli paragneiss would indeed have a Cretaceous depositional age.

\section{Orthogneiss}

On balance we interpret the geochemical, tracer isotope, and $\mathrm{U}-\mathrm{Pb}$ zircon data to support a Cretaceous rather than Miocene age of igneous rock formation. Evidence in support of a Cretaceous age is the contrast in $\mathrm{Th} / \mathrm{U}$ of the zircons (Cretaceous $=$ igneous values, Miocene $=$ metamorphic values, Fig. 5), the high LILE content of the rocks (similar to Houhora Complex, Fig. 4D), and the initial ${ }^{87} \mathrm{Sr} /{ }^{86} \mathrm{Sr}$ and $\varepsilon N d$ ratios which should be more similar to the paragneisses if the granite was a Miocene melt from the host rock (Fig. 4E,F). We attribute the imperfect match in the petrochemistry of the Cavalli samples with the onland Houhora samples to (1) aforementioned small datasets, and (2) the presence between onland Northland and Cavalli Seamount of the strike-slip VMFZ. This means that Cavalli Seamount may have originated up to $500 \mathrm{~km}$ northwest of its present position (Fig. 7) (Mortimer et al. 2007).
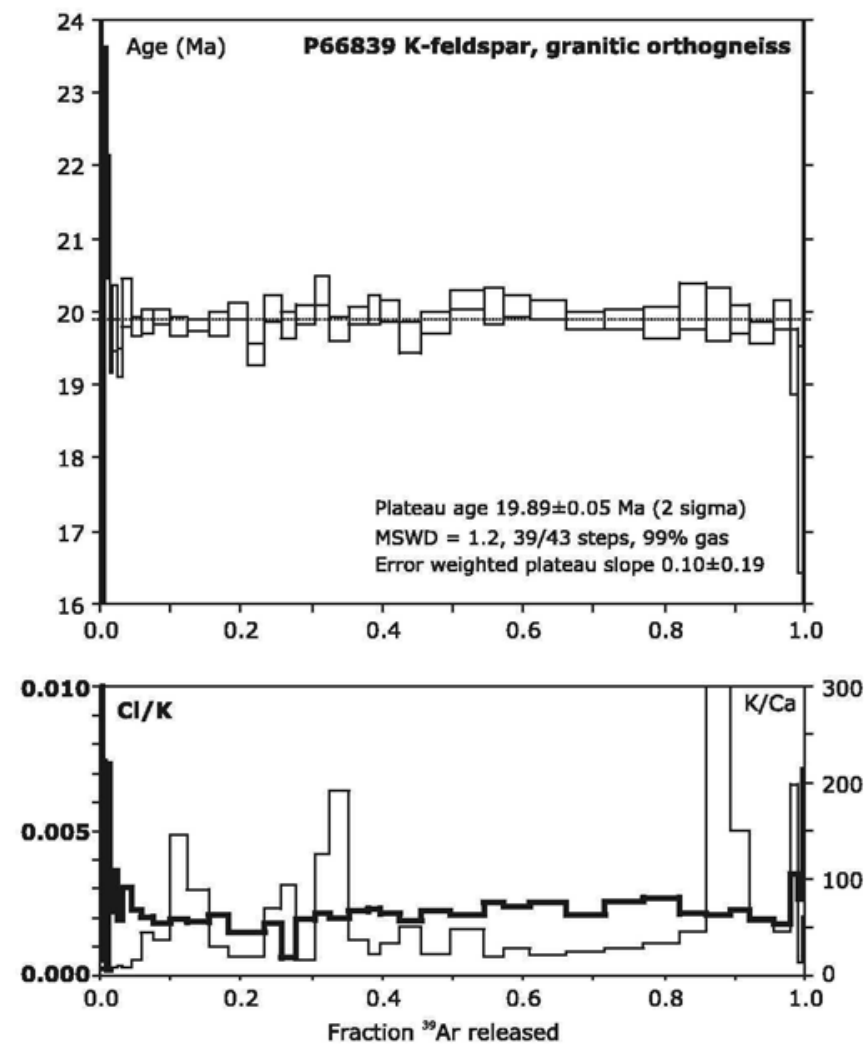

Fig. $6{ }^{40} \mathrm{Ar} /{ }^{39} \mathrm{Ar}$ age spectrum (age versus fraction of ${ }^{39} \mathrm{Ar}$ released) and accompanying $\mathrm{K} / \mathrm{Ca}$ and $\mathrm{K} / \mathrm{Cl}$ ratios for $\mathrm{K}$-feldspar from granitic orthogneiss P66839. 
Table 3 U-Th- $\mathrm{Pb}$ isotope data for Cavalli paragneiss $\mathrm{P} 66836$.

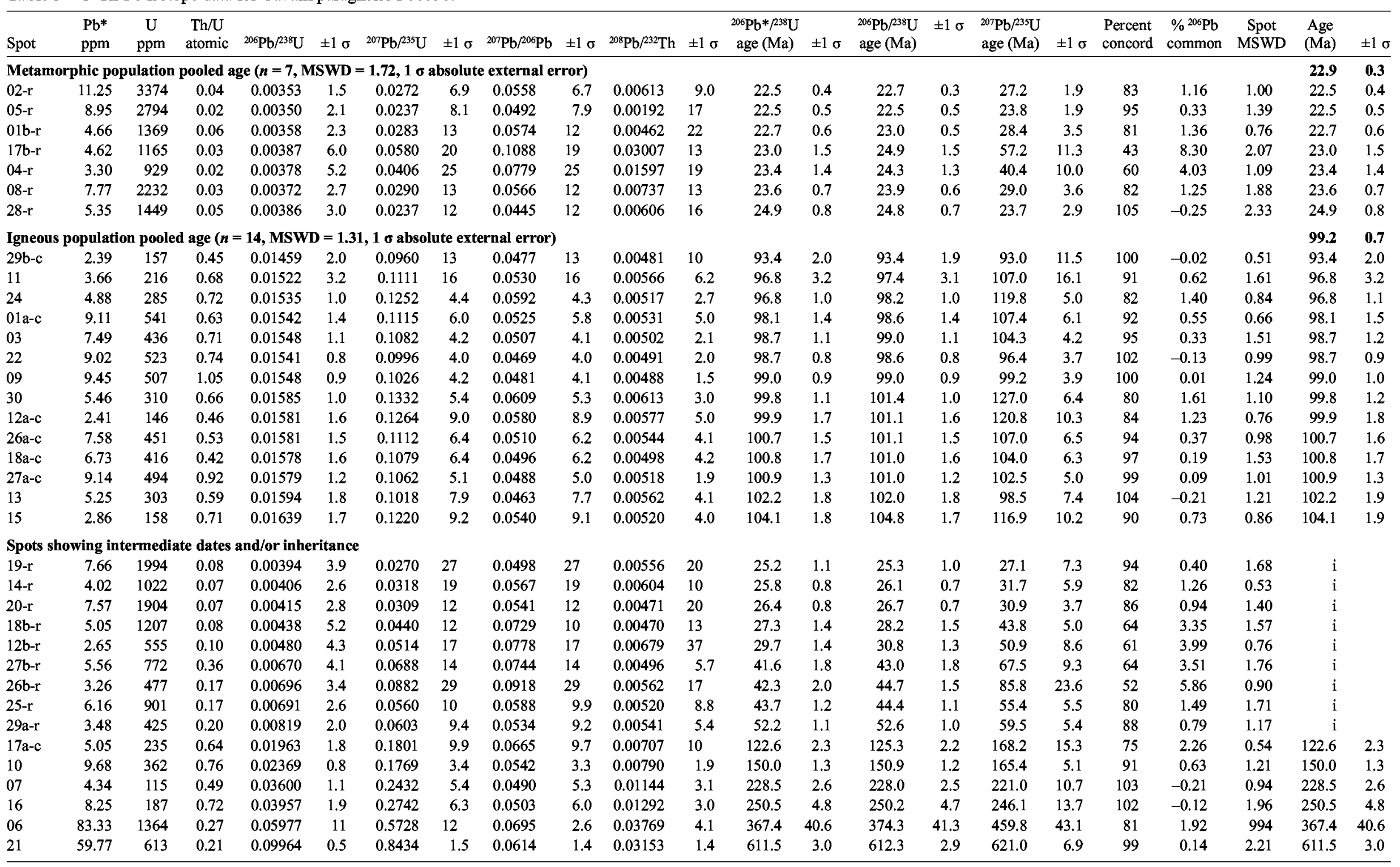

$*=$ radiogenic component only $\left({ }^{207} \mathrm{~Pb}\right.$-based common- $\mathrm{Pb}$ correction), $\mathrm{a} / \mathrm{b}=$ two ages resolved from progressive drilling of a single zoned single spot, $\mathrm{r}=$ rim, $\mathrm{c}=$ core analysis where zonation is evident, $\mathrm{i}=\mathrm{intermediate}$ date of no geological significance. 


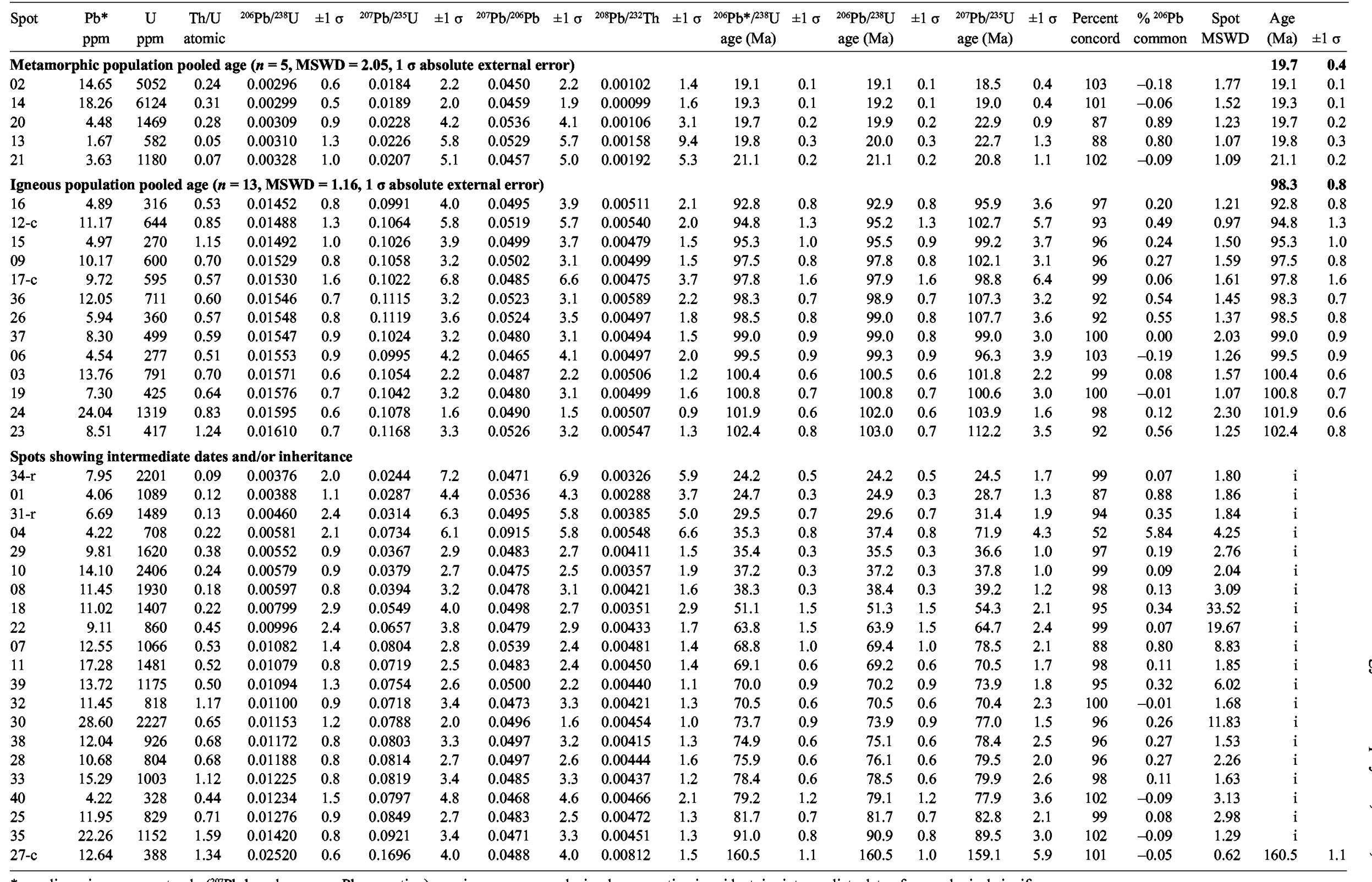

$*=$ radiogenic component only $\left({ }^{207} \mathrm{~Pb}\right.$-based common- $\mathrm{Pb}$ correction $), \mathrm{r}=\mathrm{rim}, \mathrm{c}=$ core analysis where zonation is evident, $\mathrm{i}=$ intermediate date of no geological significance. 
Table 5 Ar-Ar data for K-feldspar from P66839. $\lambda^{40} \mathrm{~K}=5.5430 \mathrm{E}-10, \mathrm{~J}=2.9195 \mathrm{E}-4$.

\begin{tabular}{|c|c|c|c|c|c|c|c|c|c|c|c|c|c|}
\hline $\mathrm{T}\left({ }^{\circ} \mathrm{C}\right)$ & ${ }^{36} \mathrm{Ar}(\mathrm{mol})$ & ${ }^{37} \mathrm{Ar}(\mathrm{mol})$ & ${ }^{38} \mathrm{Ar}(\mathrm{mol})$ & ${ }^{39} \mathrm{Ar}(\mathrm{mol})$ & ${ }^{40} \mathrm{Ar}(\mathrm{mol})$ & $\%{ }^{40} \mathrm{Ar}^{*}$ & ${ }^{40} \mathrm{Ar} * \beta^{\beta 9} \mathrm{Ar}(\mathrm{K})$ & $\mathrm{Cum}^{39} \mathrm{Ar}$ & Age & \pm & $1 \sigma$ & $\mathrm{Ca} / \mathrm{K}$ & $\mathrm{Cl} / \mathrm{K}$ \\
\hline 450 & $9.853 \mathrm{E}-16$ & $3.033 \mathrm{E}-17$ & $3.228 \mathrm{E}-16$ & $3.404 \mathrm{E}-16$ & $3.169 \mathrm{E}-13$ & 8.1 & 75.79 & 0.1 & 39.48 & \pm & 8.24 & $1.69 \mathrm{E}-01$ & $3.43 \mathrm{E}-02$ \\
\hline 450 & $1.249 \mathrm{E}-16$ & $8.530 \mathrm{E}-17$ & $1.732 \mathrm{E}-16$ & $1.311 \mathrm{E}-15$ & $3.842 \mathrm{E}-14$ & 3.9 & 1.144 & 0.7 & 0.60 & \pm & 1.81 & $1.24 \mathrm{E}-01$ & $5.33 \mathrm{E}-04$ \\
\hline 500 & $1.676 \mathrm{E}-16$ & $1.557 \mathrm{E}-17$ & $9.911 \mathrm{E}-17$ & $3.575 \mathrm{E}-16$ & $6.434 \mathrm{E}-14$ & 23.0 & 41.42 & 0.9 & 21.69 & \pm & 1.72 & $8.28 \mathrm{E}-02$ & $7.39 \mathrm{E}-03$ \\
\hline 500 & $1.043 \mathrm{E}-16$ & $6.029 \mathrm{E}-17$ & $9.165 \mathrm{E}-17$ & $4.146 \mathrm{E}-16$ & $4.877 \mathrm{E}-14$ & 36.8 & 43.27 & 1.0 & 22.64 & \pm & 0.98 & $2.76 \mathrm{E}-01$ & $5.47 \mathrm{E}-03$ \\
\hline 550 & $2.603 \mathrm{E}-16$ & $2.410 \mathrm{E}-18$ & $2.138 \mathrm{E}-16$ & $8.740 \mathrm{E}-16$ & $1.125 \mathrm{E}-13$ & 31.6 & 40.68 & 1.4 & 21.30 & \pm & 0.84 & $5.24 \mathrm{E}-03$ & $7.33 \mathrm{E}-03$ \\
\hline 550 & $6.069 \mathrm{E}-17$ & $1.226 \mathrm{E}-16$ & $1.463 \mathrm{E}-16$ & $9.125 \mathrm{E}-16$ & $5.205 \mathrm{E}-14$ & 65.5 & 37.39 & 1.8 & 19.59 & \pm & 0.43 & $2.55 \mathrm{E}-01$ & $2.23 \mathrm{E}-03$ \\
\hline 600 & $2.255 \mathrm{E}-16$ & $9.073 \mathrm{E}-17$ & $2.880 \mathrm{E}-16$ & $1.542 \mathrm{E}-15$ & $1.253 \mathrm{E}-13$ & 46.8 & 38.02 & 2.4 & 19.92 & \pm & 0.45 & $1.12 \mathrm{E}-01$ & $3.66 \mathrm{E}-03$ \\
\hline 600 & $5.624 \mathrm{E}-17$ & $9.602 \mathrm{E}-17$ & $2.675 \mathrm{E}-16$ & $1.767 \mathrm{E}-15$ & $8.170 \mathrm{E}-14$ & 79.6 & 36.83 & 3.2 & 19.29 & \pm & 0.20 & $1.03 \mathrm{E}-01$ & $1.93 \mathrm{E}-03$ \\
\hline 650 & $2.059 \mathrm{E}-16$ & $1.578 \mathrm{E}-16$ & $4.455 \mathrm{E}-16$ & $2.634 \mathrm{E}-15$ & $1.622 \mathrm{E}-13$ & 62.5 & 38.45 & 4.3 & 20.14 & \pm & 0.34 & $1.14 \mathrm{E}-01$ & $3.05 \mathrm{E}-03$ \\
\hline 650 & $5.305 \mathrm{E}-17$ & $1.095 \mathrm{E}-16$ & $5.099 \mathrm{E}-16$ & $3.374 \mathrm{E}-15$ & $1.433 \mathrm{E}-13$ & 89.0 & 37.81 & 5.8 & 19.81 & \pm & 0.14 & $6.17 \mathrm{E}-02$ & $2.27 \mathrm{E}-03$ \\
\hline 700 & $1.830 \mathrm{E}-16$ & $5.105 \mathrm{E}-17$ & $6.735 \mathrm{E}-16$ & $4.370 \mathrm{E}-15$ & $2.199 \mathrm{E}-13$ & 75.4 & 37.92 & 7.6 & 19.86 & \pm & 0.16 & $2.22 \mathrm{E}-02$ & $2.03 \mathrm{E}-03$ \\
\hline 700 & $3.972 \mathrm{E}-17$ & $7.937 \mathrm{E}-17$ & $8.099 \mathrm{E}-16$ & $5.555 \mathrm{E}-15$ & $2.233 \mathrm{E}-13$ & 94.7 & 38.08 & 10.0 & 19.95 & \pm & 0.10 & $2.71 \mathrm{E}-02$ & $1.81 \mathrm{E}-03$ \\
\hline 750 & $1.231 \mathrm{E}-16$ & $2.092 \mathrm{E}-17$ & $8.690 \mathrm{E}-16$ & $5.809 \mathrm{E}-15$ & $2.561 \mathrm{E}-13$ & 85.7 & 37.80 & 12.4 & 19.80 & \pm & 0.14 & $6.84 \mathrm{E}-03$ & $1.95 \mathrm{E}-03$ \\
\hline 750 & $4.144 \mathrm{E}-17$ & $4.203 \mathrm{E}-17$ & $1.035 \mathrm{E}-15$ & $7.087 \mathrm{E}-15$ & $2.804 \mathrm{E}-13$ & 95.6 & 37.82 & 15.4 & 19.81 & \pm & 0.08 & $1.13 \mathrm{E}-02$ & $1.86 \mathrm{E}-03$ \\
\hline 800 & $1.360 \mathrm{E}-16$ & $1.085 \mathrm{E}-16$ & $9.398 \mathrm{E}-16$ & $6.225 \mathrm{E}-15$ & $2.759 \mathrm{E}-13$ & 85.4 & 37.85 & 18.1 & 19.83 & \pm & 0.16 & $3.31 \mathrm{E}-02$ & $2.11 \mathrm{E}-03$ \\
\hline 800 & $4.437 \mathrm{E}-17$ & $1.782 \mathrm{E}-16$ & $9.863 \mathrm{E}-16$ & $6.898 \mathrm{E}-15$ & $2.767 \mathrm{E}-13$ & 95.2 & 38.20 & 21.0 & 20.01 & \pm & 0.12 & 4.91E-02 & $1.47 \mathrm{E}-03$ \\
\hline 850 & $1.455 \mathrm{E}-16$ & $1.359 \mathrm{E}-16$ & $7.690 \mathrm{E}-16$ & $5.221 \mathrm{E}-15$ & $2.366 \mathrm{E}-13$ & 81.8 & 37.06 & 23.2 & 19.41 & \pm & 0.16 & $4.95 \mathrm{E}-02$ & $1.51 \mathrm{E}-03$ \\
\hline 850 & $6.505 \mathrm{E}-17$ & $4.440 \mathrm{E}-17$ & $8.667 \mathrm{E}-16$ & $5.905 \mathrm{E}-15$ & $2.453 \mathrm{E}-13$ & 92.1 & 38.26 & 25.8 & 20.04 & \pm & 0.18 & $1.43 \mathrm{E}-02$ & $1.84 \mathrm{E}-03$ \\
\hline 900 & $1.751 \mathrm{E}-16$ & $2.739 \mathrm{E}-17$ & $6.939 \mathrm{E}-16$ & $4.894 \mathrm{E}-15$ & $2.370 \mathrm{E}-13$ & 78.1 & 37.83 & 27.8 & 19.82 & \pm & 0.18 & $1.06 \mathrm{E}-02$ & $6.34 \mathrm{E}-04$ \\
\hline 900 & $9.178 \mathrm{E}-17$ & $2.036 \mathrm{E}-16$ & $9.135 \mathrm{E}-16$ & $6.165 \mathrm{E}-15$ & $2.624 \mathrm{E}-13$ & 89.6 & 38.15 & 30.4 & 19.98 & \pm & 0.13 & $6.28 \mathrm{E}-02$ & $1.92 \mathrm{E}-03$ \\
\hline 950 & $1.856 \mathrm{E}-16$ & $2.104 \mathrm{E}-17$ & $7.755 \mathrm{E}-16$ & $5.030 \mathrm{E}-15$ & $2.499 \mathrm{E}-13$ & 78.0 & 38.76 & 32.6 & 20.30 & \pm & 0.20 & $7.95 \mathrm{E}-03$ & $2.15 \mathrm{E}-03$ \\
\hline 950 & $1.666 \mathrm{E}-16$ & $1.686 \mathrm{E}-17$ & $9.270 \mathrm{E}-16$ & $6.138 \mathrm{E}-15$ & $2.809 \mathrm{E}-13$ & 82.4 & 37.73 & 35.2 & 19.76 & \pm & 0.16 & $5.22 \mathrm{E}-03$ & $1.99 \mathrm{E}-03$ \\
\hline 950 & $2.524 \mathrm{E}-16$ & $9.641 \mathrm{E}-17$ & $1.049 \mathrm{E}-15$ & $6.767 \mathrm{E}-15$ & $3.325 \mathrm{E}-13$ & 77.5 & 38.09 & 38.1 & 19.95 & \pm & 0.12 & $2.71 \mathrm{E}-02$ & $2.25 \mathrm{E}-03$ \\
\hline 1000 & $2.878 \mathrm{E}-16$ & $9.832 \mathrm{E}-17$ & $6.595 \mathrm{E}-16$ & $4.074 \mathrm{E}-15$ & $2.409 \mathrm{E}-13$ & 64.7 & 38.23 & 39.8 & 20.02 & \pm & 0.20 & 4.59E-02 & $2.32 \mathrm{E}-03$ \\
\hline 1000 & $2.847 \mathrm{E}-16$ & $9.711 \mathrm{E}-17$ & $9.552 \mathrm{E}-16$ & $6.126 \mathrm{E}-15$ & $3.184 \mathrm{E}-13$ & 73.5 & 38.22 & 42.4 & 20.02 & \pm & 0.16 & $3.01 \mathrm{E}-02$ & $2.15 \mathrm{E}-03$ \\
\hline 1050 & $4.791 \mathrm{E}-16$ & $7.605 \mathrm{E}-17$ & $1.147 \mathrm{E}-15$ & $7.271 \mathrm{E}-15$ & $4.145 \mathrm{E}-13$ & 65.8 & 37.51 & 45.5 & 19.65 & \pm & 0.21 & $1.99 \mathrm{E}-02$ & $1.92 \mathrm{E}-03$ \\
\hline 1050 & $4.380 \mathrm{E}-16$ & $2.335 \mathrm{E}-16$ & $1.558 \mathrm{E}-15$ & $9.986 \mathrm{E}-15$ & $5.082 \mathrm{E}-13$ & 74.5 & 37.92 & 49.7 & 19.86 & \pm & 0.14 & $4.44 \mathrm{E}-02$ & $2.23 \mathrm{E}-03$ \\
\hline 1050 & $3.958 \mathrm{E}-16$ & $1.203 \mathrm{E}-16$ & $1.686 \mathrm{E}-15$ & $1.096 \mathrm{E}-14$ & $5.391 \mathrm{E}-13$ & 78.3 & 38.48 & 54.4 & 20.16 & \pm & 0.14 & $2.08 \mathrm{E}-02$ & $2.12 \mathrm{E}-03$ \\
\hline 1100 & $2.983 \mathrm{E}-16$ & $1.685 \mathrm{E}-16$ & $1.020 \mathrm{E}-15$ & $6.423 \mathrm{E}-15$ & $3.345 \mathrm{E}-13$ & 73.6 & 38.35 & 57.1 & 20.09 & \pm & 0.24 & $4.98 \mathrm{E}-02$ & $2.51 \mathrm{E}-03$ \\
\hline 1100 & $2.994 \mathrm{E}-16$ & $1.742 \mathrm{E}-16$ & $1.457 \mathrm{E}-15$ & $9.397 \mathrm{E}-15$ & $4.490 \mathrm{E}-13$ & 80.3 & 38.35 & 61.1 & 20.09 & \pm & 0.16 & $3.52 \mathrm{E}-02$ & $2.39 \mathrm{E}-03$ \\
\hline 1100 & $3.629 \mathrm{E}-16$ & $2.965 \mathrm{E}-16$ & $1.862 \mathrm{E}-15$ & $1.193 \mathrm{E}-14$ & $5.638 \mathrm{E}-13$ & 80.9 & 38.25 & 66.2 & 20.03 & \pm & 0.13 & $4.72 \mathrm{E}-02$ & $2.54 \mathrm{E}-0$ \\
\hline 1100 & $4.463 \mathrm{E}-16$ & $2.786 \mathrm{E}-16$ & $1.997 \mathrm{E}-15$ & $1.303 \mathrm{E}-14$ & $6.266 \mathrm{E}-13$ & 78.9 & 37.96 & 71.7 & 19.88 & \pm & 0.11 & $4.06 \mathrm{E}-02$ & $2.10 \mathrm{E}-03$ \\
\hline 1100 & $5.234 \mathrm{E}-16$ & $2.269 \mathrm{E}-16$ & $1.950 \mathrm{E}-15$ & $1.231 \mathrm{E}-14$ & $6.226 \mathrm{E}-13$ & 75.1 & 38.00 & 77.0 & 19.90 & \pm & 0.13 & $3.50 \mathrm{E}-02$ & $2.56 \mathrm{E}-03$ \\
\hline 1100 & $6.819 \mathrm{E}-16$ & $1.926 \mathrm{E}-16$ & $1.999 \mathrm{E}-15$ & $1.234 \mathrm{E}-14$ & $6.692 \mathrm{E}-13$ & 69.9 & 37.87 & 82.2 & 19.84 & \pm & 0.21 & 2.97E-02 & $2.69 \mathrm{E}-03$ \\
\hline 1100 & $8.628 \mathrm{E}-16$ & $1.034 \mathrm{E}-16$ & $1.473 \mathrm{E}-15$ & $8.904 \mathrm{E}-15$ & $5.967 \mathrm{E}-13$ & 57.2 & 38.36 & 86.0 & 20.09 & \pm & 0.31 & $2.21 \mathrm{E}-02$ & $2.15 \mathrm{E}-03$ \\
\hline 1100 & $1.520 \mathrm{E}-15$ & $2.700 \mathrm{E}-19$ & $1.512 \mathrm{E}-15$ & $8.354 \mathrm{E}-15$ & $7.677 \mathrm{E}-13$ & 41.5 & 38.13 & 89.5 & 19.97 & \pm & 0.37 & $6.14 \mathrm{E}-05$ & $2.10 \mathrm{E}-03$ \\
\hline 1200 & $5.165 \mathrm{E}-16$ & $2.127 \mathrm{E}-17$ & $9.964 \mathrm{E}-16$ & $6.069 \mathrm{E}-15$ & $3.833 \mathrm{E}-13$ & 60.2 & 37.99 & 92.1 & 19.90 & \pm & 0.20 & $6.66 \mathrm{E}-03$ & $2.27 \mathrm{E}-03$ \\
\hline 1230 & $1.708 \mathrm{E}-16$ & $7.225 \mathrm{E}-17$ & $1.159 \mathrm{E}-15$ & $7.738 \mathrm{E}-15$ & $3.420 \mathrm{E}-13$ & 85.2 & 37.66 & 95.4 & 19.72 & \pm & 0.15 & $1.77 \mathrm{E}-02$ & $1.96 \mathrm{E}-03$ \\
\hline 1260 & $1.537 \mathrm{E}-16$ & $7.041 \mathrm{E}-17$ & $9.203 \mathrm{E}-16$ & $6.179 \mathrm{E}-15$ & $2.810 \mathrm{E}-13$ & 83.8 & 38.12 & 98.0 & 19.96 & \pm & 0.20 & $2.17 \mathrm{E}-02$ & $1.78 \mathrm{E}-03$ \\
\hline 1290 & $1.223 \mathrm{E}-16$ & $6.911 \mathrm{E}-18$ & $4.344 \mathrm{E}-16$ & $2.605 \mathrm{E}-15$ & $1.322 \mathrm{E}-13$ & 72.6 & 36.87 & 99.1 & 19.32 & \pm & 0.44 & $5.04 \mathrm{E}-03$ & $3.49 \mathrm{E}-03$ \\
\hline 1320 & $1.694 \mathrm{E}-16$ & $3.722 \mathrm{E}-17$ & $1.805 \mathrm{E}-16$ & $9.846 \mathrm{E}-16$ & $8.384 \mathrm{E}-14$ & 40.3 & 34.30 & 99.5 & 17.98 & \pm & 1.55 & $7.18 \mathrm{E}-02$ & $2.63 \mathrm{E}-03$ \\
\hline 1350 & $3.118 \mathrm{E}-16$ & $1.498 \mathrm{E}-17$ & $1.248 \mathrm{E}-16$ & $4.112 \mathrm{E}-16$ & $1.081 \mathrm{E}-13$ & 14.7 & 38.71 & 99.7 & 20.27 & \pm & 4.84 & $6.92 \mathrm{E}-02$ & 3.87E-03 \\
\hline 1450 & $4.313 \mathrm{E}-15$ & $5.773 \mathrm{E}-18$ & $9.353 \mathrm{E}-16$ & $6.672 \mathrm{E}-16$ & $1.301 \mathrm{E}-12$ & 2.0 & 39.22 & 100.0 & 20.54 & \pm & 23.78 & $1.64 \mathrm{E}-02$ & $7.11 \mathrm{E}-03$ \\
\hline Total & $1.653 \mathrm{E}-14$ & $4.091 \mathrm{E}-15$ & $3.789 \mathrm{E}-14$ & $2.354 \mathrm{E}-13$ & $1.380 \mathrm{E}-11$ & & 37.88 & & 19.84 & \pm & 0.29 & & \\
\hline
\end{tabular}



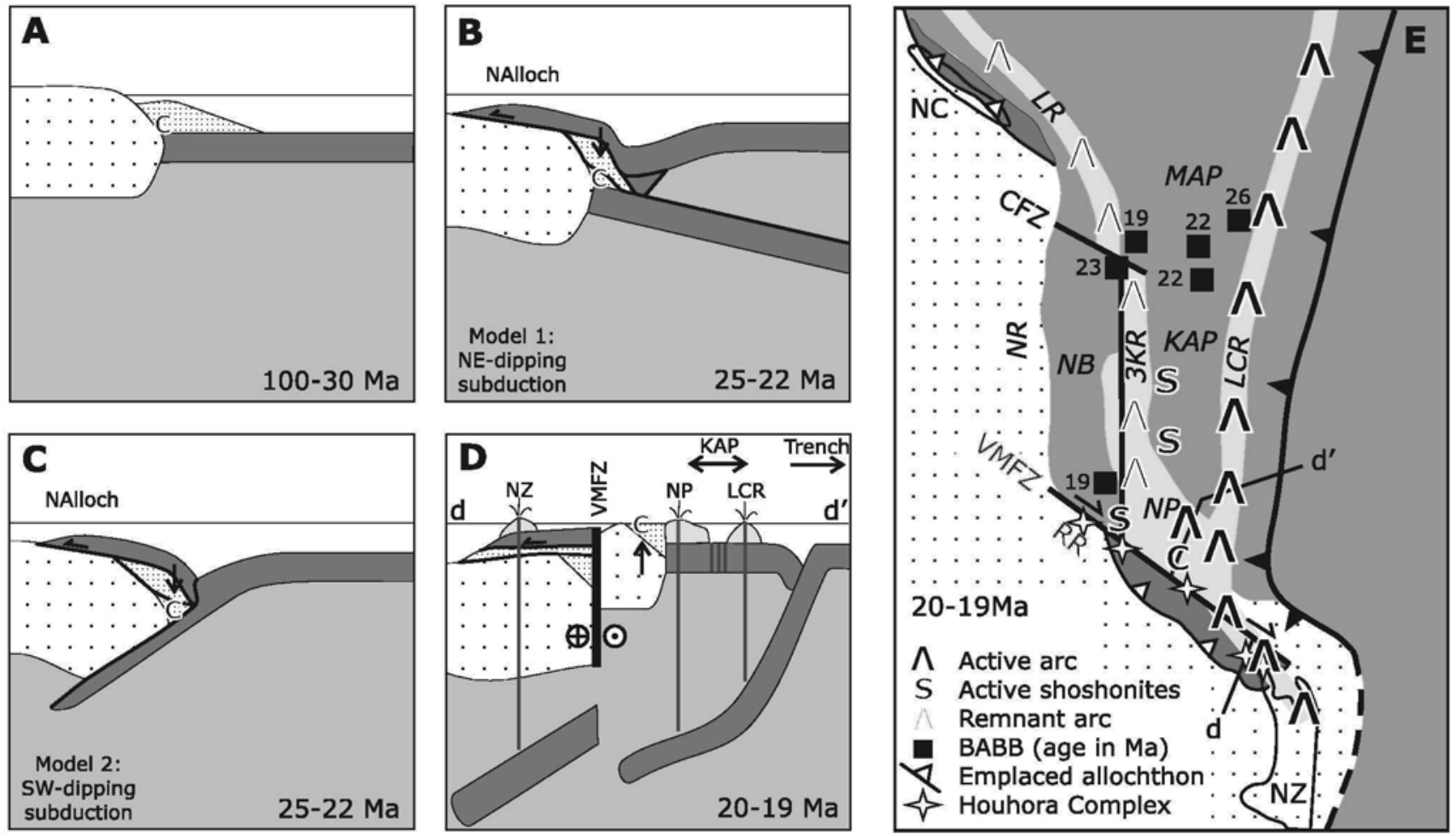

Fig. 7 Schematic cross-sections and map showing tectonic context of Cavalli Seamount (C) in the Oligocene-Miocene. Cross-sections are based on Malpas et al. (1992) and oriented approximately northeast-southwest across the continental margin between New Zealand (NZ) and the Reinga Ridge (RR). Arrows emphasise significant vertical and horizontal motion. A, Late Cretaceous Cavalli protoliths deposited near bottom of sediment wedge on older Mesozoic orogen. B, Northeast-dipping subduction model for Northland Allochthon emplacement. C, Southwest-dipping subduction model for Northland Allochthon emplacement. D, Rapid post-allochthon, early Miocene exhumation to sea level of Cavalli Seamount can be related to dextral (and possibly transtensional) strike-slip movement on the Vening Meinesz Fracture Zone (VMFZ), Pacific trench rollback, an opening Kupe Abyssal Plain back-arc basin, and widespread subduction-related volcanism and shoshonitic rift-related volcanism. Twin subducted slabs are derived from different along-strike portions of the same Pacific slab on different sides of the VMFZ. Cross-section line $d-d^{\prime}$ is offset on VMFZ. E, Map view showing features described in panel D. NZ $=$ New Zealand, $\mathrm{NC}=$ New Caledonia, $\mathrm{NP}=$ Northland Plateau, VMFZ $=$ Vening Meinesz Fracture Zone, $\mathrm{CFZ}=\mathrm{Cook}$ Fracture Zone, $\mathrm{NB}=$ Norfolk Basin, MAP = Minerva Abyssal Plain, KAP $=$ Kupe Abyssal Plain, NR $=$ Norfolk Ridge, $3 \mathrm{KR}=$ Three Kings Ridge, TKR $=$ Tong-Kermadec Ridge, $\mathrm{LR}=$ Loyalty Ridge, $\mathrm{BABB}=$ back-arc basin basalt dredge site.

We interpret the dated orthogneiss sample and smaller granitic veins (Table 1) to have been parts of subvolcanic dikes and plutons that intruded a Late Cretaceous silicic volcanic-volcaniclastic carapace, similar to the case of the Houhora Complex (Isaac et al. 1994; Isaac 1996). As such, the broad similarity between orthogneisses and paragneiss bulk rock compositions need not be coincidence. We do not entirely rule out some remobilisation and/or migmatisation of the Cretaceous protoliths in the early Miocene (e.g., at the time of intrusion of the Karikari Plutonics).

\section{Metamorphism and exhumation}

Mortimer et al. (2003) were unable to constrain the age of prograde amphibolite facies metamorphism of the schists and gneisses. The new U-Pb data presented in Fig. 5 indicate metamorphic zircon growth possibly as early as $23 \mathrm{Ma}$ and possibly as late as $20 \mathrm{Ma}$. This definitely seems to link the prograde metamorphism with other early Miocene events in onland and offshore Northland (Mortimer et al. 2003, 2007), rather than to some Cretaceous or Paleogene event. The Ar-Ar dating of a single separate of K-feldspar from West Cavalli (P66839) provides a simpler and less ambiguous cooling history than the multiple minerals and methods used by Mortimer et al. (2003) for the East Cavalli dredge site. P66839 underwent exceptionally rapid cooling rates of c. $2000^{\circ} \mathrm{C} /$ Ma through the $350-150^{\circ} \mathrm{C}$ temperature range at $19.9 \mathrm{Ma}$. The cooling interval of 23-21 Ma cited by Mortimer et al. (2003) was arrived at by the need to accommodate a $25 \pm 4$ Ma zircon fission track age. While different parts of Cavalli may have been exhumed at different times (the 1999 and 2002 sample sites are $20 \mathrm{~km}$ apart), the current study would appear to provide a more precise and consistent result, with which all thermochronological and micropaleontological data of Mortimer et al. (2003), except the zircon fission track age, are entirely compatible. The inferred vertical exhumation rate of c. $100 \mathrm{~mm} / \mathrm{yr}$ is comparable to moderately fast horizontal plate tectonic rates and matches the inferred $67-100 \mathrm{~mm} / \mathrm{yr}$ rate calculated for the VMFZ from the alignment of Kupe Abyssal Plain hotspot tracks (Mortimer et al. 2007).

\section{Tectonic model}

From the combined results of the 1999 and 2002 dredges, Cavalli Seamount protoliths are now known to consist of correlatives of Late Cretaceous-Paleogene sedimentary cover derived from Waipapa Terrane (Mortimer et al. 2003) and also Late Cretaceous sedimentary and plutonic rocks similar to Houhora Complex (this study) (Fig. 7A). Both these rock units are present in autochthonous basement of present day onland 
Northland, although the Cavalli rocks may actually have been ripped off the continental Reinga Ridge many hundreds of kilometres to the northwest where Houhora-like rocks are known to occur (Mortimer et al. 1998). This arises as a simple consequence of the position of Cavalli Seamount oceanward of the VMFZ (Fig. 1), and of closing the Norfolk Basin, and perhaps parts of Kupe Abyssal Plain, along the VMFZ (Fig. 7) (Herzer \& Mascle 1996; Mortimer et al. 2007).

The Northland Allochthon was emplaced in the interval 25-22 Ma, thus it is plausible to associate the $23-20 \mathrm{Ma}$ Cavalli high grade metamorphism with crustal thickening associated with allochthon emplacement, similar to models of Eocene allochthon emplacement and metamorphism in New Caledonia (Cluzel et al. 2001; Crawford et al. 2003). The recovery of plutonic and metamorphic rocks of similar, amphibolite facies, metamorphic grade from a wide area on Cavalli Seamount (Fig. 2) would seem to argue against the rocks occurring as a thin sub-allochthon metamorphic sole (one option considered by Mortimer et al. 2003) but would suggest a distribution throughout a more significant crustal volume. Two different scenarios for tectonic burial of the Cavalli rocks to amphibolite facies depths in thickened crust beneath the Northland Allochthon are presented in Fig. 7B, C (after Malpas et al. 1992). Neither the present study, nor that of Mortimer et al. (2007), is able to provide a test of the polarity of emplacement of the Northland Allochthon.

The early Miocene was a time of intense tectonomagmatic activity and change in and near northern New Zealand. Mortimer et al. (2007) attributed this to tandem opening of the Norfolk and Kupe back-arc basins behind a rapidly east-retreating Pacific trench, separated from the continental crust of Zealandia by the VMFZ (Fig. 7D,E). Between the southern Norfolk Basin and offshore Northland, the VMFZ is known to be a major dextral strike-slip fault system (Isaac et al. 1994; Herzer \& Mascle 1996).

The exhumation event in which Cavalli schists and gneisses came from c. $10 \mathrm{~km}$ depth to exposure and planation at sea level by the Altonian (19-17 Ma) (Mortimer et al. 2003) is now more accurately and precisely dated at $19.9 \mathrm{Ma}$ and inferred to have had an exceptional vertical exhumation rate of c. $100 \mathrm{~mm} / \mathrm{yr}$. Exhumation clearly followed the 25-22 Ma emplacement of the Northland Allochthon. The images of stretching lineations and sediment-filled cracks (Fig. 3A,B) provide outcrop information that was unavailable to Mortimer et al. (2003) that also can be fitted into a model. Unfortunately, we do not know if the Cavalli rocks are part of a longer linear belt, or are a unique point occurrence.

Mortimer et al. (2003) noted that the rapid early Miocene exhumation of Cavalli Seamount was consistent with it being in the lower plate of an early Miocene metamorphic core complex. Our new data still support this conclusion but we can now better identify the tectonic controls on exhumation. Fast rates of vertical exhumation of metamorphic rocks have been associated with extensional metamorphic core complexes where oceanic spreading ridges propagate into continental borderlands (e.g., $>10 \mathrm{~mm} / \mathrm{yr}$ exhumation rate, Baldwin et al. 2004), with continent-continent collision zones (e.g., $34 \mathrm{~mm} / \mathrm{yr}$, Rubatto \& Hermann 2001; 6-9 mm/yr, Little et al. 2005) and in complex back-arc basin settings (e.g., >4 mm/yr, Thomson et al. 1998; Ring \& Reishmann 2002). Core complex formation and exhumation has also been described from intracontinental strike-slip regimes (e.g., Whitney et al. 2007). Although the $10 \mathrm{~km}$ paleodepth estimates for the Cavalli gneisses is not well constrained, the inferred exhumation rate far exceeds the aforementioned estimates which are generally considered to be fast (see also Ring et al. 1999). We believe that the extreme Cavalli exhumation rate is a result of the coincidence in space and time of multiple tectonic conditions favouring local vertical motion. Contributing factors to the rapid exhumation were probably: (1) up to $100 \mathrm{~mm} / \mathrm{yr}$ dextral motion on the adjacent VMFZ; (2) rapid Pacific trench rollback; (3) possible soft link to a coeval rapid back-arc spreading in the Kupe Abyssal Plain; and (4) buoyancy-assisted uplift of an overthickened continental crust fragment against the VMFZ.

Figure 7D,E shows Cavalli Seamount in this regional context of dextral transform faulting with subduction- and rift-related volcanoes erupting on both sides of the VMFZ. Improved understanding of the regional kinematic significance of Cavalli Seamount must await seismic surveys of the Northland continental margin to better define controlling structures, and local multibeam bathymetric mapping of Cavalli Seamount to enable matching of our hand sample and outcrop scale data with regional scale fault patterns.

\section{CONCLUSIONS}

Two cruises to Cavalli Seamount in 2002 added to the material obtained on an earlier cruise in 1999 (Mortimer et al. 2003). The 2002 cruises yielded outcrop photographs, more samples of high grade metasedimentary rocks, and, for the first time, metaplutonic rocks. Our analytical work indicates that Late Cretaceous protoliths similar to Houhora Complex are present on West Cavalli, as well as the previously established Waipapa Terrane-derived sedimentary cover rocks on East Cavalli. U-Pb dating of zircons indicates amphibolite facies (sillimanite grade) metamorphism to have taken place in the interval $20-23 \mathrm{Ma}$, and is plausibly related to crustal thickening associated with emplacement of the Northland Allochthon. Ar-Ar dating of K-feldspar indicates that ultrafast exhumation took place at 19.9 Ma. Extremely rapid mid-crustal exhumation took place in a regime of intra-arc dextral transtension between the VMFZ and a retreating Pacific trench.

\section{ACKNOWLEDGMENTS}

We are grateful to the Captain and crew of the RVs Tangaroa and Kaharoa for successful cruises in 2002. Neville Orr, John Simes, Belinda Smith Lyttle, and John Hunt provided their usual high quality technical support. Comments from two anonymous referees helped improve the content of the paper. We also thank the Australian Institute of Nuclear Science and Engineering (AINSE) and the Australian Nuclear Science Technology Organisation (ANSTO) for facilitating irradiation of samples. Funded by the New Zealand Foundation for Research Science and Technology (FRST) Contract CO5X0703 (Physical Resources of the Oceans programme). NIWA's cruise was funded by FRST Contract CO1X0508 (Seamount Biodiversity and Processes).

\section{REFERENCES}

Adams CJ, Pankhurst RJ, Maas R, Millar IL 2005. Nd and Sr isotopic signatures of metasedimentary rocks around the South Pacific margin and implications for their provenance. Geological Society of London Special Publication 246: 113-141. 
Adams CJ, Campbell HJ, Griffin WL 2007. Provenance comparisons of Permian to Jurassic tectonostratigraphic terranes in New Zealand: perspectives from detrital zircon age patterns. Geological Magazine 144: 701-729.

Baldwin SL, Monteleone BD, Webb LE, Fitzgerald PG, Grove M, Hill EJ 2004. Pliocene eclogite exhumation at plate tectonic rates in eastern Papua New Guinea. Nature 431: 263-267.

Clark M, Downing K, O'Shea S, Thomas C 2002. Voyage report of a survey of seamounts off the northeast coast of the North Island (KAH0204). Wellington, National Institute of Water and Atmospheric Research. 11 p.

Cluzel D, Aitchison JC, Picard C 2001. Tectonic accretion and underplating of mafic terranes in the late Eocene intraoceanic forearc of New Caledonia (Southwest Pacific): geodynamic implications. Tectonophysics 340: 23-59.

Compton RR 1985. Geology in the field. New York, John Wiley \& Sons.

Crawford AJ, Meffre S, Symonds PA 2003. 120 to 0 Ma tectonic evolution of the southwest Pacific and analogous geological evolution of the 600 to $220 \mathrm{Ma}$ Tasman Fold Belt System. Geological Society of America Special Paper 372: 383-403.

Dunlap WJ 2000. Nature's diffusion experiment: the cooling-rate cooling-age correlation. Geology 28: 139-142.

Dunlap WJ 2003. Crystallization versus cooling ages of white micas: dramatic effect of $\mathrm{K}$-poor inclusions on ${ }^{40} \mathrm{Ar} /{ }^{39} \mathrm{Ar}$ age spectra. Journal of the Virtual Explorer 13, Paper 3.

Herzer RH, Mascle J 1996. Anatomy of a continent-backarc transform - the Vening Meinesz Fracture Zone northwest of New Zealand. Marine Geophysical Research 18: 401-427.

Herzer RH, Mascle J, Davy B, Ruellan E, Mortimer N, Laporte C, Duxfield A 2000. New constraints on the New ZealandSouth Fiji Basin continent-back-arc margin. Comptes Rendu de l'Académie des Sciences, Paris, Sciences de la Terre et des Planètes 330: 701-708.

Herzer RH, Davy B, Mortimer N, Laporte-Magoni C, Barker D 2004. Cruise report-GNS Cruise SF0202 "ONSIDE II" (Offshore Northland Seismic and Dredging Expedition II). Institute of Geological \& Nuclear Sciences File Report 2004-01.

Hoskin PWO, Schaltegger U 2003. The composition of zircon and igneous and metamorphic petrogenesis. Reviews in Mineralogy and Geochemistry 53: 27-62.

Isaac MJ comp. 1996. Geology of the Kaitaia area. Institute of Geological \& Nuclear Sciences 1:250 000 Geological Map 1. Lower Hutt, New Zealand, Institute of Geological \& Nuclear Sciences Ltd.

Isaac MJ, Herzer RH, Brook FJ, Hayward BW 1994. Cretaceous and Cenozoic sedimentary basins of Northland, New Zealand. Institute of Geological \& Nuclear Sciences Monograph 8.

Little TA, Cox S, Vry JK, Batt G 2005. Variations in exhumation level and uplift rate along the oblique-slip Alpine fault, central Southern Alps, New Zealand. Geological Society of America Bulletin 117: 707-723.

Malpas J, Spörli KB, Black PM, Smith IEM 1992. Northland ophiolite, New Zealand, and implications for plate-tectonic evolution of the southwest Pacific. Geology 20: 149-152.

McCulloch MT, Kyser TK, Woodhead JD, Kinsley K 1994. Pb-Sr$\mathrm{Nd}-\mathrm{O}$ isotopic constraints on the origin of rhyolites from the Taupo Volcanic Zone of New Zealand: evidence for assimilation followed by fractionation from basalt. Contributions to Mineralogy and Petrology 115: 303-312.

Middlemost EAK 1994. Naming materials in the magma/igneous rock system. Earth Science Reviews 37: 215-224.

Mitchell JS, Eade JV 1990. North Cape bathymetry. New Zealand Oceanographic Institute Chart, coastal series, 1:200 000.
Mortimer N, Herzer RH, Gans PB, Parkinson DL, Seward D 1998 Basement geology from Three Kings Ridge to West Norfolk Ridge, southwest Pacific Ocean: evidence from petrology, geochemistry and isotopic dating of dredge samples. Marine Geology 148: 135-162.

Mortimer N, Herzer RH, Walker NW, Calvert AT, Seward D, Chaproniere GCH 2003. Cavalli Seamount, Northland Plateau, SW Pacific Ocean: a Miocene metamorphic core complex? Journal of the Geological Society (London) 160: 971-983

Mortimer N, Hoernle K, Hauff F, Palin JM, Dunlap WJ, Werner R, Faure K 2006. New constraints on the age and evolution of the Wishbone Ridge, southwest Pacific Cretaceous microplates, and Zealandia-West Antarctica breakup. Geology 34: 185-189.

Mortimer N, Herzer RH, Gans PB, Laporte-Magoni C, Calvert AT, Bosch D 2007. Oligocene-Miocene tectonic evolution of the South Fiji Basin and Northland Plateau, SW Pacific Ocean: evidence from petrology and dating of dredged rocks. Marine Geology 237: 1-24.

Nicholson KN, Black PM 2004. Cretaceous to early Tertiary basaltic volcanism in the Far North of New Zealand: geochemical associations and their tectonic significance. New Zealand Journal of Geology and Geophysics 47: 437-446.

Nicholson KN, Black PM, Picard C 2000. Geochemistry and tectonic significance of the Tangihua Ophiolite Complex, New Zealand. Tectonophysics 321: 1-15.

Palmer K, Mortimer N, Nathan S, Isaac MJ, Field BD, Sircombe KN, Black PM, Bush S, Orr NW 1995. Chemical and petrographic analyses of some New Zealand Paleozoic-Mesozoic metasedimentary and igneous rocks. Institute of Geological \& Nuclear Sciences Science Report 95/16. 37 p.

Ring U, Reishmann T 2002. The weak and superfast Cretan detachment, Greece: exhumation at subduction rates in extruding wedges. Journal of the Geological Society (London) 159: 225-228.

Ring U, Brandon MT, Willett SD, Lister GS 1999. Exhumation processes. Geological Society of London Special Publication 154: $1-27$.

Rubatto D 2002. Zircon trace element geochemistry: partitioning with garnet and the link between $\mathrm{U}-\mathrm{Pb}$ ages and metamorphism. Chemical Geology 184: 123-138.

Rubatto D, Herrmann J 2001. Exhumation as fast as subduction? Geology 29: 3-6.

Ruddock RS 1990. The Karikari Plutonics of Northland, New Zealand. Unpublished $\mathrm{PhD}$ thesis, University of Auckland, Auckland, New Zealand.

Spell TL, McDougall I 2003. Characterization and calibration of ${ }^{40} \mathrm{Ar} /{ }^{39} \mathrm{Ar}$ dating standards. Chemical Geology 198: 189-211.

Sun SS, McDonough WF 1989. Chemical and isotopic systematics of oceanic basalts: implications for mantle compositions and processes. Geological Society of London Special Publication 42: 313-345.

Thomson SN, Stöckhert B, Brix MA 1998. Thermochronology of the high-pressure metamorphic rocks of Crete, Greece: implications for the speed of tectonic processes. Geology 26: $259-262$.

Whalen JB, Currie KL, Chappell BW 1987. A-type granites: geochemical characteristics, discrimination and petrogenesis. Contributions to Mineralogy and Petrology 95: 407-419.

Whitney DL, Teyssier C, Heizler MT 2007. Gneiss domes, metamorphic core complexes, and wrench zones: thermal and structural evolution of the Nigde Massif, central Anatolia. Tectonics 26. TC5002, doi:10.1029/2006TC002040. 